\title{
Pasture yield and soil physical property responses to soil compaction from treading and grazing - a review
}

\author{
J. J. Drewry ${ }^{\mathrm{A}, \mathrm{B}, \mathrm{C}, \mathrm{E}}$, K. C. Cameron ${ }^{\mathrm{D}}$, and G. D. Buchan ${ }^{\mathrm{D}}$ \\ Antegrated Catchment Assessment and Management Centre, Building 48A, Linnaeus Way, The Australian \\ National University, Canberra, ACT, Australia. \\ ${ }^{B}$ Fenner School of Environment and Society, The Australian National University, Canberra, ACT, Australia. \\ ${ }^{\mathrm{C}}$ Cooperative Research Centre for Landscape Environments and Mineral Exploration, The Australian National \\ University, Canberra, ACT, Australia. \\ ${ }^{D}$ Centre for Soil and Environmental Quality, Soil and Physical Sciences Group, PO Box 84, Lincoln University, \\ New Zealand. \\ ${ }^{\mathrm{E}}$ Corresponding author. Current address: Mackay Whitsunday Natural Resource Management Group, \\ PO Box 815, Mackay, Qld 4740, Australia. Email: john.drewry@anu.edu.au or john@mwnrm.org.au
}

\begin{abstract}
This paper reviews animal treading and the associated effects on soil physical properties and pasture productivity from treading-induced soil compaction and pugging. Response curve relationships between soil physical properties (e.g. macroporosity, air-filled porosity, bulk density) and pasture and crop yield are reviewed. Optimum soil macroporosity for maximum pasture and crop yield ranges from 6 to $17 \% \mathrm{v} / \mathrm{v}$, but there is a paucity of yield response curves for pastoral systems, particularly critical or optimum values of soil physical properties. There is little information available on the effects of cattle treading on soil physical properties and consequently pasture yield in seasons when soil pugging and poaching is minimised. Such information is needed to provide practical and rigorously tested decision support tools for land managers during grazing seasons. Knowledge of yield response curves, and critical or optimum values of soil physical properties for field pasture-based grazing systems, is required for improved farm-system production and economic decision support.
\end{abstract}

Additional keywords: compaction, pugging, treading, poaching, indicator, pasture yield, macropore, bulk density, soil quality, indicator, trampling, cattle.

\section{Introduction}

Globally, livestock-based agriculture continues to intensify, and there is increasing concern regarding its environmental impacts such as deforestation, overgrazing causing compaction, soil degradation, erosion, and water pollution (Steinfeld et al. 2006). About $20 \%$ of the world's pastures and rangelands are considered degraded through overgrazing and compaction (Steinfeld et al. 2006). Clearing of Amazon rain forest and subsequent cattle trampling can degrade soil physical condition and greatly reduce pasture competitiveness and yield (Martínez and Zinck 2004). Soil compaction by animal treading can have detrimental impacts on soil physical conditions and also plant growth. Hence, indicators of physical condition and health are an important area of research, and are increasingly being included in environmental reporting (Sparling et al. 2004). Soil physical degradation, treading-induced damage, and reduced plant and pasture cover also contribute to erosion and surface runoff to waterways under semi-arid and temperate climates (e.g. Greene et al. 1994; Eldridge 1998; McDowell et al. 2004; Kurz et al. 2006). Erosion and surface runoff effects from treading are outside the scope of this review.
Many studies have reported reduced pasture growth following a single intensive treading or pugging event where a considerable amount of pasture damage was sustained. Such treading events and trials are commonly imposed during very wet conditions. For example, visual pugging damage following high-density winter grazing by cattle (grazed at 300 cows/ha for $0,3,9$, or $24 \mathrm{~h}$ ) took up to 29 weeks to recover to the level of untreaded plots, whereas the effect of pugging on hydraulic conductivity lasted only 1-3 months (Zegwaard et al. 2000). Although Zegwaard et al. (2000) presented no time frame, their study also reported an initial reduction in pasture production of $51 \%$ following 24 -h duration grazing treatment (described above), but due to favourable growing conditions following damage, full recovery of pasture growth was reached after the 14th week (Zegwaard et al. 2000).

Although many other trials studied the effects of animal treading on pasture production and soil properties (e.g. Scholefield et al. 1985; Cluzeau et al. 1992; Greenwood et al. 1997; Ward and Greenwood 2002; Menneer et al. 2005; Pande and Yamamoto 2006), it is often difficult to determine direct $v$. indirect effects on pasture quantity. Pasture yield responses to treading may be due 
to direct damage to pasture plants, which includes both plant damage through hoof action accompanied by visible disruption of soil aggregates and plant burial in muddy conditions from pugging damage in temperate climates (Menneer et al. 2005; Zegwaard 2006). Direct damage is often visible to land managers. Greater hoof activity with high stocking rates in semi-arid rangelands may directly damage plants and pulverise the soil surface (Greene et al. 1994). Yield reduction may also occur from indirect effects. These indirect effects on pasture yield include changes in soil physical conditions, such as reduced pore space from compaction. Such changes during treading may not be as visually evident as direct soil damage, e.g. pugging and surface smearing, but can have large effects on plant growth (Cannell 1977; Carter 1988; Drewry et al. 2001).

Soil compaction and yield decline may occur in seasons such as moist summer or autumn periods, particularly in temperate climates, but this area of study requires further research. In contrast, with the intensive winter-grazing and direct damage effects when excess moisture prevails in temperate climates (e.g. Menneer et al. 2005), grazing during spring, summer, or autumn may cause less soil damage. Under pastoral (e.g. dairy, beef cattle, and sheep) grazing systems, soil may be subject to compaction damage when there is little visual evidence of surface damage or disturbance. Simulated treading or compaction in controlled environments, however, has attempted to minimise, control, or separate the direct effects of plant crushing, bruising, and injury from those of changes in soil physical conditions (e.g. Moore and Laidlaw 1980; Ferrero 1991; Drewry et al. 2001).

To assist farm managers to optimise pasture growth, it would be useful to establish relationships between soil physical properties and pasture yield to enable management tools to be developed (Drewry et al. 2004a). Response relationships between yield and soil physical properties (response curves) have been derived for many crops and conditions (e.g. Canarache et al. 1984; Carter 1990; Kayombo and Lal 1994), but generally not for pastoral grazing systems. Macroporosity and air-filled porosity are good indicators of soil physical condition, with values of $<10-12 \%$ often used to indicate limiting conditions for plant health and soil aeration (Greenland 1981; Carter 1988, 1990). Carter (1988), in a study of the cereals spring barley (Hordeum vulgare) and spring wheat (Triticum aestivum), found that the relationship between macroporosity and saturated hydraulic conductivity indicated that $8-14 \%$ macroporosity would maintain adequate soil permeability. Carter (1990) identified 12-14\% macroporosity as adequate for aeration. Further research is required to determine these types of relationships for pasture and treading management to enable better understanding, particularly of economic effects of soil physical quality at paddock and farm system scales. Such information will enable land managers to make more informed management decisions.

This review focuses on animal treading and the associated effects on soil physical properties and pasture productivity in both pugged and compacted non-pugged soil. The emphasis is to review pastoral yield response curve relationships over the continuum of soil physical property values. We start with an overview of some principles of soil compaction, consistency, and the effects of soil moisture and grazing-treading management. The effects of animal treading on pasture productivity and selected soil physical properties are reviewed - a comprehensive review of effects of all soil physical properties is beyond the scope of this paper. Simulation studies of treading and compaction effects on plant yield are also discussed, as such studies are useful to minimise the direct plant damage during treading.

Emphasis is placed on reviewing effects of soil physical properties on plant growth, particularly response relationships and critical and optimum values of soil physical properties for maximum plant yield. Although there has been much research on the effects of management on compaction in cropping systems, much of this research may not apply directly to pastoral systems due to different tolerances to soil physical conditions compared with established pasture, and the added complication of animal grazing and treading interactions. Because there is little equivalent research published for pastoral systems, we also review research for cropping systems, in particular relating yield response curves to soil compaction. Finally, we outline tools and management of soil physical condition and pasture yields on-farm, and areas for future research.

\section{Principles of soil compaction \\ Definitions}

Soil compaction has been traditionally described as 'the compression of an unsaturated soil body resulting in a reduction of the fractional air volume' (Hillel 1980). The effect of compaction is to decrease the total porosity, particularly the volume of the large inter-aggregate pores. Once the air volume is reduced, or the soil is saturated, then the term consolidation can be used (Hillel 1980). Consolidation is the compression of a saturated soil brought about by squeezing out water. Consolidation is a more gradual process than compaction, as the viscosity of water is much greater than air. Poaching or puddling, in contrast to compaction, are terms used for slurry-induced soil conditions on very wet soil (often in winter-grazed management systems in moisture-excess climates) when trampled by stock. Pugging in wet, soft soil causes deep hoof imprints and is often associated with considerable pasture damage. In this review, pastoral damage from soil pugging and poaching is considered to be direct damage, whereas pastoral yield response to compaction is considered an indirect response.

\section{Soil moisture, consistency, and compaction}

Soil consistency (e.g. hard, friable) and compaction are very dependent on the level of moisture. Very dry soil is hard and resists deformation, while wetter friable soil will break up easily. When soil deforms rather than breaks up, it is said to be in a plastic state (McLaren and Cameron 1996). Figure 1 shows the relationship of soil consistency to water content and the risk of compaction and pugging damage.

The plastic limit of a soil is the gravimetric water content at which a soil changes from being friable to being plastic, and represents the minimum amount of water at which pugging and 


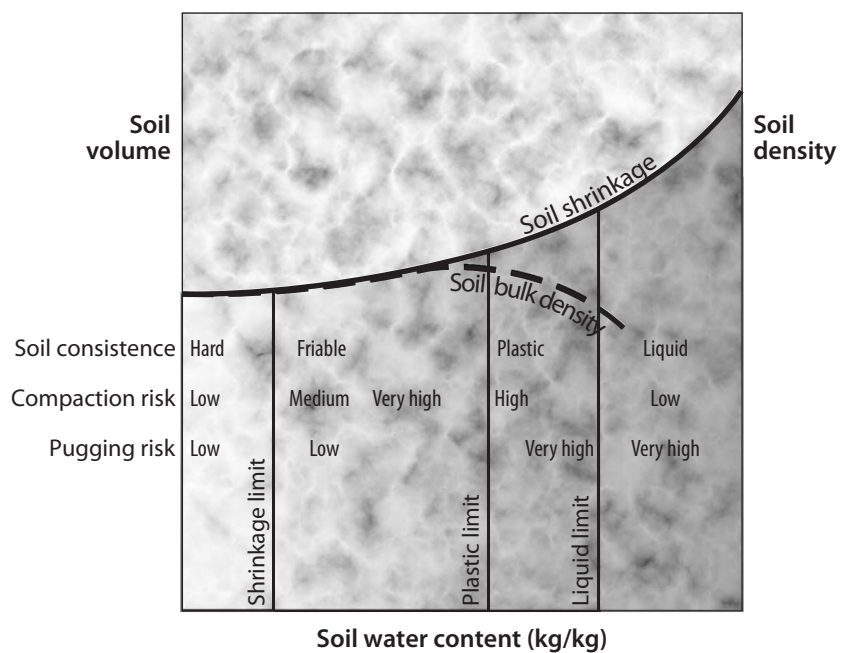

Fig. 1. Schematic diagram of relationship of soil consistency and gravimetric water content (adapted from Marshall and Holmes 1988). The risk of compaction and pugging damage is also shown. Soil water range between plastic and liquid limits and damage risk varies with soil properties such as texture. The solid line shows soil shrinkage; the dashed line shows soil bulk density including maximum density.

puddling may occur (McLaren and Cameron 1996). For some soils the field capacity (see definition next section) is close to the plastic limit. If soil moisture at field capacity is lower than the plastic limit, treading or cultivation at close to field capacity should be avoided as the soil is likely to be compacted (Mapfumo and Chanasyk 1998).

When a soil is subjected to compaction, starting from a dry condition, its bulk density will increase with increasing moisture due to a particle lubricating effect, until a maximum soil density is reached which will occur at an 'optimum' moisture (Hillel 1980). The maximum bulk density (hence maximum compaction) $v$. wetness corresponds to $\sim 80 \%$ of the degree of saturation (Hillel 1980). Beyond saturation, soil particles are pushed further apart, reducing bulk density. Figure 1 shows the relationship of bulk density to soil water content. Under standardised conditions this relationship is measured using the Proctor test, and varies with texture and other properties, so other concepts (Carter 1990; Lipiec and Hakansson 2000) including relative compaction and degree of compactness are discussed below.

Pugging by stock commonly occurs at lower soil moisture than for poaching, although soils with high clay contents are more prone to damage. Plastic flow predominates around the hoof when the soil is very wet (Scholefield et al. 1985; Mulholland and Fullen 1991). However, because of uneven distribution of water in the soil profile, compression in deeper layers may also occur.

The liquid limit (upper plastic limit) of a soil is the gravimetric water content at which a soil changes from being plastic and starts to behave as a viscous liquid when an external force is applied (McLaren and Cameron 1996). At the liquid limit, a soil is very prone to puddling and poaching. The physical damage caused by treading may involve both compaction at low to medium water contents (e.g. during spring, summer, or autumn in summer moisture-deficit climates), or soil poaching and pugging at high water contents (e.g. early spring or winter in moisture-excess winter climates), depending on treading management. Trafficking of soil should generally be avoided near and beyond the plastic limit or field capacity, whichever is less (Mapfumo and Chanasyk 1998).

Soil moisture content at consistency limits varies with texture, depth, and organic carbon content. Examples of gravimetric soil moisture $(\mathrm{kg} / \mathrm{kg})$ for a sandy loam were maximum bulk density at 0.14 , field capacity 0.15 (at $-33 \mathrm{kPa}$ ), plastic limit 0.25 , and liquid limit 0.30 (Mapfumo and Chanasyk 1998). Gravimetric soil moistures $(\mathrm{kg} / \mathrm{kg})$ for a clay loam were maximum bulk density at 0.24 , field capacity 0.35 , plastic limit 0.27 , and liquid limit 0.51 (Mapfumo and Chanasyk 1998). Gravimetric soil moistures $(\mathrm{kg} / \mathrm{kg})$ for a silt loam were plastic limit $0.30-0.36$, and liquid limit $0.60-0.81$, depending on soil depth (Singleton and Addison 1999).

\section{Soil physical properties}

As a measurement of soil compaction, bulk density, the mass of soil per unit volume, can give an indication of the level of compaction, or conversely porosity (McLaren and Cameron 1996).

Macroporosity describes the volume percentage of pores $>30 \mu \mathrm{m}$ equivalent diameter (McLaren and Cameron 1996). Macropores are primarily responsible for adequate soil aeration and rapid drainage of water and solutes (McLaren and Cameron 1996). However, macropores have also been defined with different equivalent pore diameters (Table 1), which must be considered when making comparisons between studies. The volume and functional effectiveness of large pores are most susceptible to reduction when soil is compacted, by vehicles or animal treading. Macroporosity was demonstrated by Ball et al. (2007) to be a very good and sensitive indicator of soil physical condition.

Air-filled porosity is the ratio of the volume of air to the total volume of soil (Cameron and Buchan 2006). It is dependent on soil moisture content. Air-filled porosity is often calculated at field capacity (McLaren and Cameron 1996). The definition

Table 1. Macroporosity as defined in the literature

\begin{tabular}{lc}
\hline References & Pore diameter $>x \mu \mathrm{m}$ \\
\hline Greenwood and McNamara (1992) & 30 \\
McLaren and Cameron (1996) & 30 \\
Singleton and Addison (1999) & 30 \\
Drewry et al. $(2000$, 2001, 2004a, 2004b) & 30 \\
Menneer et al. $(2005)$ & 30 \\
Houlbrooke et al. (2006) & 30 \\
Kurz et al. (2006) & 30 \\
Carter (1988, 1990) & 50 \\
Gradwell (1960, 1965) & 60 \\
Climo and Richardson (1984) & 60 \\
Glinski and Lipiec (1990) & 100 \\
Koppi et al. (1992) & 195 \\
\hline
\end{tabular}


of macroporosity above (i.e. volumetric percentage of pores $>30 \mu \mathrm{m}$ diameter) represents the air-filled porosity at field capacity (Cameron and Buchan 2006). Hence, when measured at the same matric potential, they can be considered equivalent.

If the soil air-filled porosity is $<10 \%(\mathrm{v} / \mathrm{v})$ at field capacity, then drainage is recommended (McLaren and Cameron 1996). Field capacity has been described as the volumetric water content of the soil following $48 \mathrm{~h}$ of drainage, from an initially saturated state, or determined in the laboratory commonly at a matric potential of $-10 \mathrm{kPa}$ (McLaren and Cameron 1996).

Soil compaction and consolidation can cause detrimental changes in physical properties, particularly decreases in macroporosity and air-filled porosity, and increases in bulk density.

\section{Treading management and treading intensities}

Soil physical condition and pasture responses depend on grazing management (and hence treading damage) regimes and climatic conditions. Pasture and soil damage is greatest when pasture stocking coincides with high soil moisture. Much of the soil structural damage, for example, in temperate climates is therefore likely to occur in when animals are grazed while soil moisture is high, and particularly when stocking density is high. This section briefly outlines treading management that is relevant to this review. Low stocking density grazing for high production, for example, is compared to management under high stock densities.

Grazing systems in temperate areas, e.g. New Zealand and southern Australia, are predominantly pasture-based, with rotational grazing during periods of greatest production. A rotational dairy grazing system, e.g. with 14-21 days between paddock grazing, is common on southern New Zealand dairy farms from September to May (i.e. during lactation), giving a grazing paddock density of $\sim 70-90$ cows/ ha for $24 \mathrm{~h}$ (Drewry and Paton 2000). Under these circumstances, soil moisture varies over spring-autumn, with frequent deficits during summer in this region. Grazing systems in Australia and New Zealand include summer irrigation where available. Rotational grazing in Tasmania, for example, is commonly 21-28 days with irrigation (from November to May), and 40 days without (Lobry de Bruyn and Kingston 1997). Other high stocking rate grazing systems are practised in other periods of the year.

In other regions and countries, rotational grazing systems have local variations based on regional and climate constraints, e.g. time-control grazing systems in temperate grasslands. Time-control grazing in southern Australia attempts to encompass a landscape-wide and holistic management approach to reduce land degradation that may occur under set-stocked regimes (Earl and Jones 1996; Anderson 2004). Soil physical quality has been shown to improve in rotational grazing systems compared with set-stocking systems (stock grazed continuously per paddock), possibly as a result of more vigorous pasture cover (Southorn and Cattle 2004).

In contrast to rotational grazing, during winter in southern regions of New Zealand, 'dry' (not milked) dairy cattle are normally completely removed from the farm milking area, so pasture is not grazed or treaded. This can have the effect of transferring potential soil damage from treading in excess moisture conditions to other farms where these animals are grazed. Wet winter and spring pugging damage by cows is also an important limitation for dairying in Victoria and Tasmania, Australia (Nie et al. 2001; Ward et al. 2003). Grazing cattle at very high densities is often reported in trials in northern areas of New Zealand as dairy cows are more likely to be grazed on-farm over winter at much higher densities than during lactation (Ledgard et al. 1996). Consequently, there is a great risk of pugging damage. Non-lactating dairy cows, for example, are 'block-grazed' in winter on blocks or strips at stock densities that can reach 300-600 cows/ha, often in wet conditions, with resulting treading damage, pugging, and poaching likely (Singleton and Addison 1999). Dairy grazing densities in winter conditions in other regions and studies under experimental conditions range from 137-350 cows/ha (Drewry 2003) up to $450 \mathrm{cows} / \mathrm{ha}$ (Menneer et al. 2005). Soil moisture in these studies was $53-83 \mathrm{~kg} / \mathrm{kg}$ (Drewry 2003) and near saturation (Menneer et al. 2005). Experimental grazing densities in winter conditions were 67-267 cows/ha in the Victorian study of Nie et al. (2001). Such grazing densities are uncommon in other grazing systems including rotational grazing systems to maintain optimum productivity, and stocking rates are commonly less in drier climates and under more extensive rangeland agriculture.

\section{Effects of treading on pasture productivity}

This section reviews the effects of animal treading on pasture productivity, and discusses the effects of intensive treading when pugging occurs in wet conditions. The effects of compaction on pasture and plant productivity, when treading-induced pugging damage does not occur, are presented later in the paper.

\section{Intensive cattle treading causing pugging damage to soil}

Animal grazing and treading, particularly in wet conditions, can affect pasture yield directly through leaf burial in mud, crushing, bruising, and a reduction in dry matter production (Hamilton and Horne 1988; Ledgard et al. 1996; Nie et al. 2001). Brown and Evans (1973) reviewed the work of Edmond, including sheep treading rates, interaction with moisture levels, soil type, herbage height, and pasture species. Herbage yields were reduced by up to $63 \%$ for high stocking rates particularly in wet conditions (Brown and Evans 1973). Perennial ryegrass (Lolium perenne) was found to be the most tolerant to heavy treading treatments in a study of the relative yields of 10 pasture species at 5 treading rates (Edmond 1964; Brown and Evans 1973). However, ryegrass yields were reduced by $5 \%$ for 20 stock units/ha and up to $23 \%$ for 80 stock units/ha relative to a non-treaded control; 1 stock unit is defined as the equivalent annual feed requirement for one $55-\mathrm{kg}$ sheep rearing a single lamb.

Large production decreases for a single intensive cattle treading event during winter were demonstrated by Ledgard et al. (1996), on a Te Kowhai silt loam (Typic Ochraqualf). 
Pasture production, for example, decreased by $20-80 \%$ relative to a non-treaded treatment, depending on soil type. The effects of pugging on yield lasted 4-8 months. Reduced infiltration and soil aeration also resulted from intensive treading. Declines in pasture productivity from other studies are shown in Table 2. Clearly, as stocking rates and treading intervals increase, the declines in pasture productivity increase (Table 2).

Under wet conditions pasture yield declines greatly when soil is pugged. Annual herbage production was reduced by $16 \%$ and $34 \%$ following moderate (walking $450 \mathrm{cows} / \mathrm{ha}$ for $1.5 \mathrm{~h}$ on $15 \mathrm{~m}^{2}$ plots) and severe (walking $450 \mathrm{cows} / \mathrm{ha}$ for $2.5 \mathrm{~h}$ ) cattle pugging (Menneer et al. 2005). Yield reductions were recorded from a single pugging event on a Te Kowhai silt loam (Typic Ochraqualf) in the Waikato region, NZ, when soil moisture was near saturation (Menneer et al. 2005). However, a greater reduction in yield of perennial ryegrass (Lolium perenne) occurred in the severe treatment with white clover (Trifolium repens). Reductions of pasture yield of $40-42 \%$ under medium to heavy pugging were also demonstrated in Victoria by Nie et al. (2001) (Table 2).

Grazing wet soils in Victoria with 'on-off' grazing (e.g. grazed for $2 \mathrm{~h}$ then removed from pasture), or subsurface drainage, reduced severity of pugging damage (Ward et al. 2003). The study of Ward et al. (2003) associated increased bulk density with lower than expected pasture yield, but further yield details were not presented. A $3 \mathrm{~h}$ (i.e. on-off) grazing treatment in a 3-year study also showed improved soil physical conditions after minimising pugging damage, but was not reflected in greater pasture production compared with $24 \mathrm{~h}$ conventional grazing (Drewry 2003). In contrast, a conventionally grazed but never-pugged treatment greatly improved soil physical condition and had greater winter/spring pasture growth in some years than conventional grazing (Drewry 2003). Farmers may therefore justify using 'stand-off' pads to remove animals from wet soils in their management, but further research is still required to fully evaluate yield benefits and whole farm system economics. Other studies of pugging damage are summarised in Table 2.

While many studies of grazing and soil properties report reduced pastoral yield, fewer studies report other agronomic indicators such as tiller numbers. However, Pande et al. (2000) determined that low spring herbage growth rates following a single winter treading of pasture on a Pallic soil (Aeric Fragiaqualf) were due largely to reduced tiller numbers and leaf area index. Under cattle treading, for example, mixed pasture perennial ryegrass (Lolium perenne), browntop (Agrostis capillaris), and yorkshire fog (Holcus lanatus) tiller numbers (recorded at 20 days after treading) were reduced by $75 \%$ in damaged pasture treatments in comparison to undamaged pasture (Pande et al. 2000). Curll and Wilkins (1983) considered the effects of treading were less important than intensity of defoliation on herbage accumulation.

While there have been studies examining effects from pugging damage, further research is required examining the pastoral effects of treading during seasons when the soil is unlikely to have been damaged by pugging. The effects of animal treading on soil physical properties are outlined in the following section, with the effects of soil physical properties on plant and pasture growth outlined later in the paper.

\section{Effects of treading on soil physical properties}

Compaction and pugging will detrimentally affect soil structure in wet conditions. Badly pugged soil will result in poor structure such as surface caps, platy structure, or increased clods of massive structure. Good soil structure has a more open pore system, with porous crumbs and very few dense aggregates (McLaren and Cameron 1996). The effects of treading on soil physical properties are outlined in the following section only. There are many soil physical properties affected by treading: bulk density, aggregate size and stability, and penetration resistance, for example, were reviewed by Greenwood and McKenzie (2001). Ball et al. (2007) concluded that macroporosity was the best indicator of soil physical fertility in their study as it was sensitive to structural changes. For these reasons we particularly highlight macroporosity and air-filled porosity in this review. First we discuss the incidence and effects of intensive cattle treading when pugging in wet conditions occurs, and then soil compaction when pugging damage does not occur.

\section{Incidence of soil compaction}

The incidence of soil compaction on farms is strongly related to soil characteristics, water content, and treading intensity. Zegwaard et al. (1998) showed, for 5 soils under dairying, that macroporosity and other soil properties may be limiting to plant growth depending on the level of treading damage and the soil type. Singleton and Addison (1999) surveyed soil physical properties including bulk density, macroporosity, saturated hydraulic conductivity $\left(\mathrm{K}_{\mathrm{sat}}\right)$, unsaturated hydraulic conductivity ( $\left.\mathrm{K}_{\text {unsat }}\right)$, and aggregate size under dairying, on 3 soil types. Singleton and Addison (1999) demonstrated a decline in values for macroporosity, $\mathrm{K}_{\text {sat, }} \mathrm{K}_{\text {unsat, and }}$ aggregate size from never-treaded sampling areas to normally grazed and previously pugged areas. Macroporosity at $50-100 \mathrm{~mm}$ in the poorly drained Hauraki clay (Melanic Orthic Gley; Aeric Fluvaquent) decreased from 16.2\% to 7.7\% in untreaded to pugged sites. Bulk density increased indicating degrading soil physical health. Declines were also apparent in Orthic Allophanic (Typic Udivitrand) soils, volcanic in origin and therefore commonly resistant to pugging damage. In a survey of 97 sheep and 87 dairy farm sites, soils on the sheep farms had significantly greater air permeability and saturated hydraulic conductivity than soils on dairy farms (Drewry et al. 2000). Macroporosity decreased from $0-50$ to $50-100 \mathrm{~mm}$ at a significantly greater rate on dairy farms than sheep farms. Drewry et al. (2000) also considered macroporosity limiting for plant growth (on some Pallic Soils; Aeric Fragiaquept), particularly under dairying.

\section{Intensive cattle treading causing pugging damage to soil}

The effects of treading under field conditions on soil physical properties, particularly macroporosity, are shown in Table 3. These studies at high stocking rates, commonly in wet conditions, cause considerable declines in pore space and $\mathrm{K}_{\text {sat }}$, even if grazed for relatively short intervals 


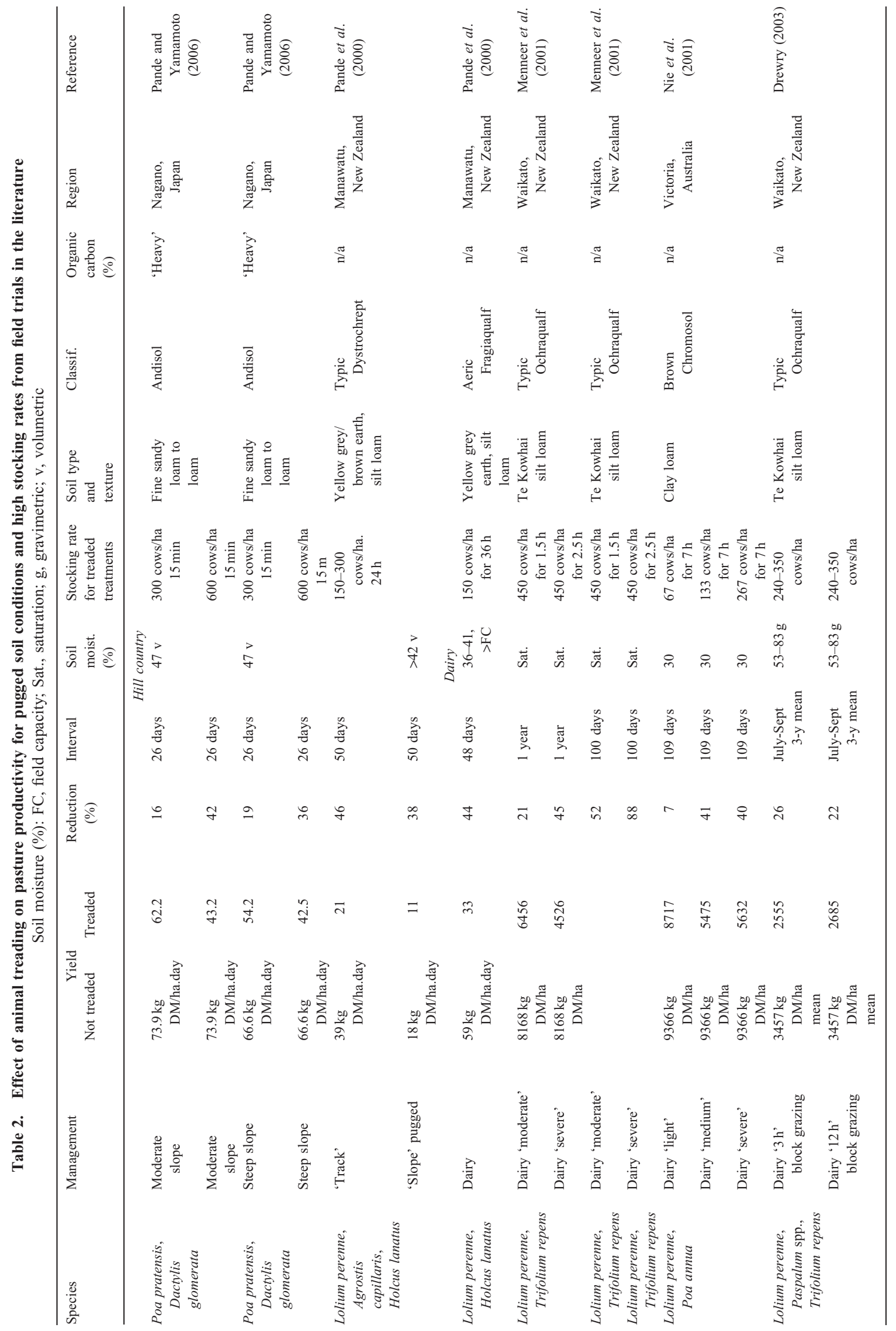




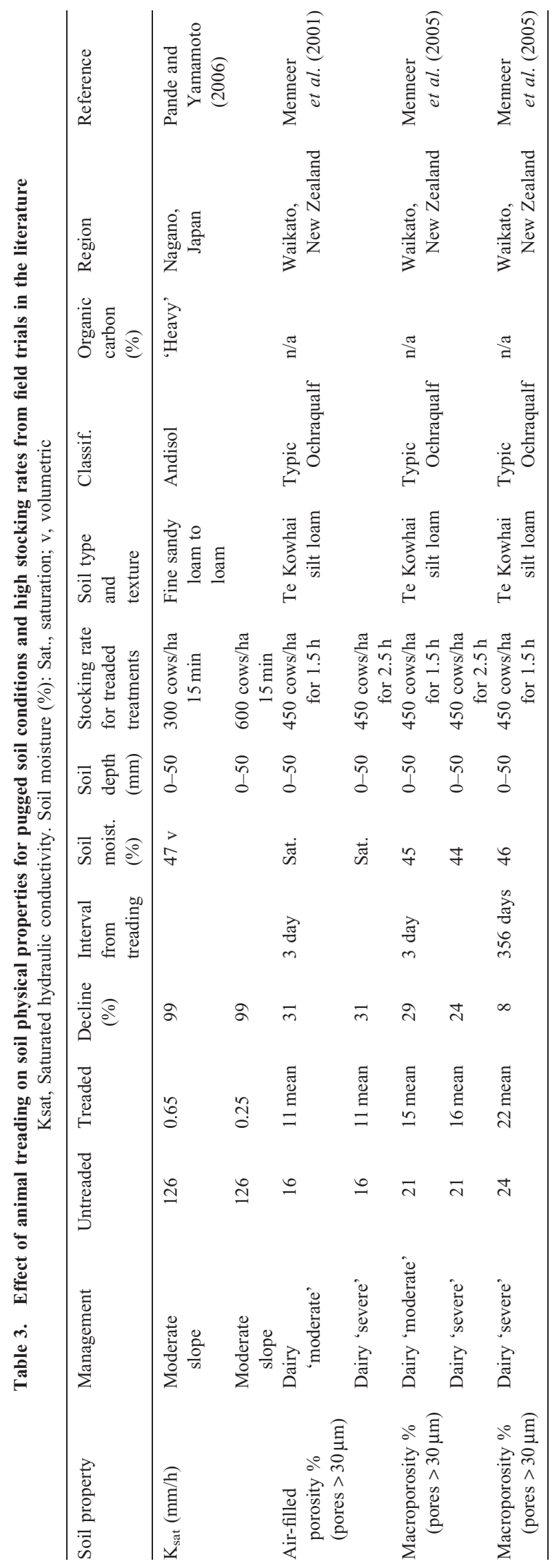


(Table 3). Surface roughness also increases with pugging damage. Mean pugging depths of 35 and $43 \mathrm{~mm}$ occurred for medium and heavy pugging treatments, respectively, when imposed in Victoria (Nie et al. 2001). Soil physical condition can however recover from pugging damage, but commonly takes many months or years (Drewry 2006).

Cattle treading increases bulk density. Mulholland and Fullen (1991), for example, reported a $21 \%$ greater bulk density on areas heavily trampled by cattle than on less trampled areas. Increases in bulk density occurred with successive grazing of wet soils in Victoria with 'on-off' grazing and subsurface drainage (Ward et al. 2003). However, the study indicated that benefits of subsurface drainage (i.e. reducing soil moisture quickly after rain) may lead to some compaction as macropores were compressed (Ward et al. 2003). The lack of compaction in undrained, saturated treatments was likely to be a result of macropores being full of water and resisting compression (Ward et al. 2003), a finding similar to several other studies (e.g. Betteridge et al. 1999). Although drainage reduces the risk and severity of poaching and pugging (Ward et al. 2003) during moisture-excess winter and spring conditions, an implication is that it may also increase the risk of compaction occurring by reducing soil water content. This can be seen in Fig. 1. Although drainage is perceived to be most useful in wet years, Horne and Singleton (1997) showed that drainage was more useful in average years than in wet years.

Most of the early work on treading by Edmond and other authors was agronomic in nature, and there were few soil physical measurements, although Edmond (1958) associated greater bulk densities with greater stocking rates. However, the usefulness of bulk density as a measure of compaction varied between trials and soil types. Gradwell (1968) showed little change in bulk density but a large change in macroporosity for treading trials, suggesting that macroporosity was a more useful measure of soil compaction. Macroporosity is, however, more time-consuming and expensive to measure than bulk density.

Topsoil total porosity was demonstrated by Gradwell (1960) not to be a reliable measure of the structural changes most likely to affect plants. Large pores to $30 \mathrm{~mm}$ depth were reduced from $10 \%$ to $3 \%$ as a result of sheep grazing in winter. Regeneration of free-draining pores took up to 2 months. Other studies are less clear, as Hamilton and Horne (1988) showed that sheep treading in winter did not significantly alter macroporosity between drained and undrained plots, although there was considerable pasture damage and poaching on undrained plots. However, Hamilton and Horne (1988) noted that macroporosity remained at $\sim 10 \%$ before and after treading. Areas of heavy trampling and poaching reduced infiltration rates by $98 \%$ compared with less trampled areas and produced very dense zones at 70-105 mm (Mulholland and Fullen 1991). Similarly, Singleton and Addison (1999) showed hydraulic conductivity had decreased by $80 \%$ at $50-100 \mathrm{~mm}$ in previously pugged areas, compared with areas that were not treaded. The importance of a balance between grazing duration and stock exclusion was demonstrated by Clifton (2005) for maintenance of soil physical structure in floodplain wetlands in south-east Australia.

\section{Treading management and soil compaction}

Despite many studies on the effects of intensive pugging (e.g. Table 3), there are fewer studies in intensive farming systems evaluating the effects of treading causing compaction where pugging/poaching damage does not occur. Declines in macroporosity are shown in Table 4 for treading studies where the extensive poaching/pugging damage does not occur. Compared with studies described in the previous section, these studies show a decline in macroporosity (and other soil physical properties) even under farming conditions that are much more likely to favour good soil 'health'.

It is thought that soil compaction (from non-pugged grazing) and recovery may occur in a cycle. The magnitude of compaction and recovery for soils prone to damage is of practical interest to farmers and researchers. The magnitude of compaction during spring, and natural recovery of soil physical properties during summer and autumn, were quantified on a Pallic soil (Aeric Fragiaquept) intermittently grazed during rotational grazing by dairy cows (Drewry et al. 2004b). Compaction of soil macropores, averaged over 3 -year spring periods, is shown in Table 4. Many of the soil physical properties at $0-50$ and $50-100 \mathrm{~mm}$ depth also showed significant recovery over summer and autumn. For many physical properties, recovery over winter was much less than for summer and autumn (Drewry et al. 2004b). Possible reasons for increased recovery of physical condition in summer and autumn in temperate environments include increased cracking and activity of soil fauna. For a review of natural recovery of physical properties under pastoral systems, readers are referred elsewhere (e.g. Drewry 2006).

Land use intensification via sheep grazing under trees (i.e. silvopastures) can result in reduced air-filled pore space compared with ungrazed areas (Sharrow 2007). Sharrow (2007) suggested that woodland grazing occurs in large areas of North America, but research on treading and soil physical properties in these areas is needed. Land use intensification via irrigation, by changing farm systems from dryland sheep grazing to irrigated cattle grazing, reduced macroporosity from $18 \%$ to $9 \%$, respectively (Houlbrooke et al. 2006). The authors noted however, that the change in soil physical health on this Fragic Pallic soil (Aeric Fragiaquept) had not significantly affected pasture yield over the 2005/06 season, suggesting that soil quality had not yet fallen below a critical level for production (Houlbrooke et al. 2006). The studies of Houlbrooke et al. (2006) and Drewry et al. (2000) indicate that some soils are more compact than others and that soils under cattle grazing are likely to be more compact than under sheep farming. However, there is a need to define values of soil physical properties that may limit pasture yield.

Pasture management in association with annual cultivation is important in parts of South Africa. Kikuyu (Pennisetum clandestinum) pastures, for example, become dominant, so temperate annual ryegrass (Lolium multiflorum) 


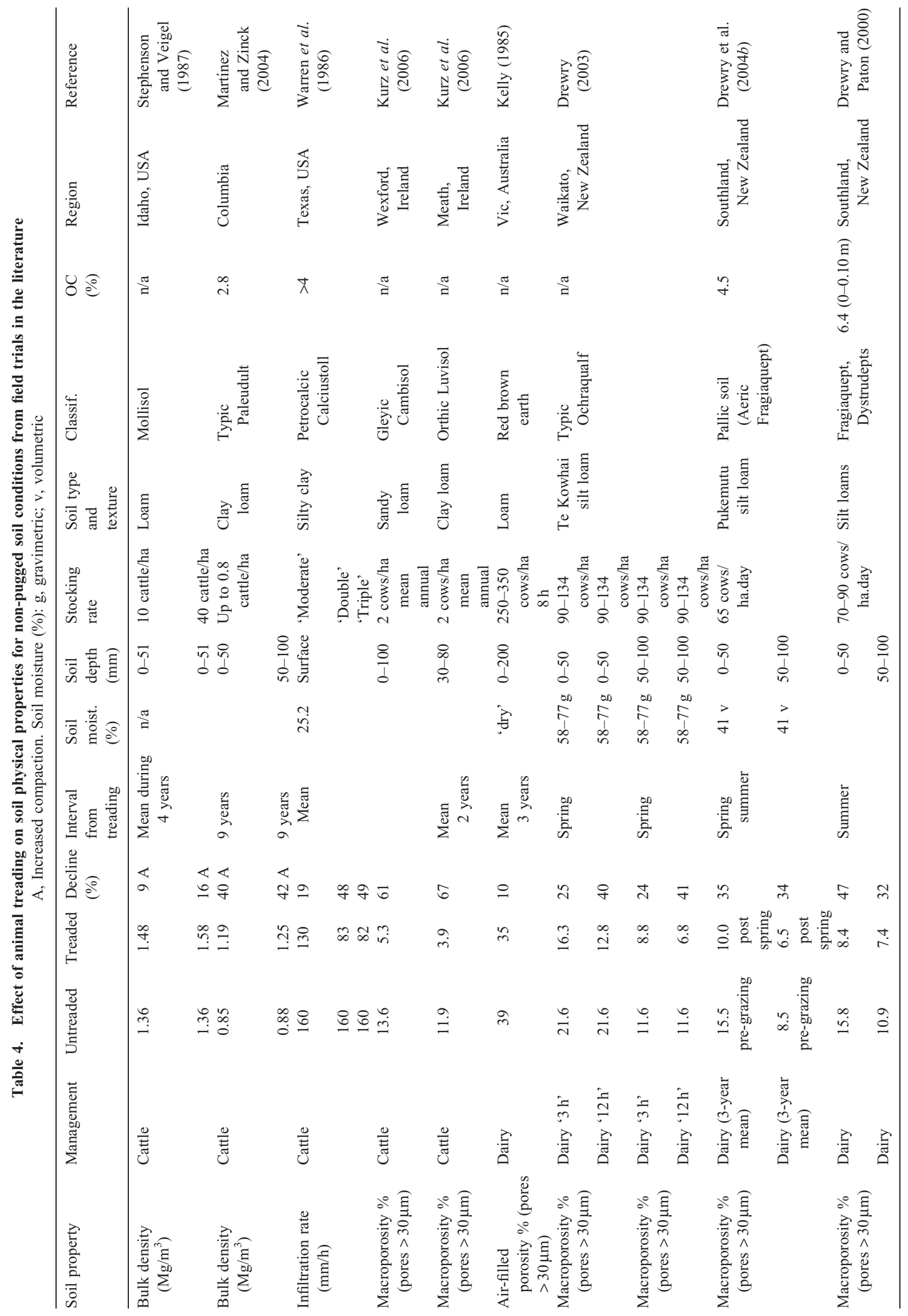


or perennial ryegrass (Lolium perenne) pastures are often sown annually to produce pasture growth during winter rotational cattle grazing (Milne and Haynes 2004). Cattle-grazed 15-year-old kikuyu pasture soil was shown to be less compact than annually tilled and resown ryegrass-based soil, from bulk density, aggregate stability, and hydraulic conductivity (Milne and Haynes 2004). Permanent pasture had greater organic carbon content than annually tilled pastures.

While this review has focused on some unfavourable aspects for soil structure following intensive grazing, we note that converting land to developed pasture also produces some counterbalancing benefits for soil structure and fertility including increases in organic matter (e.g. Conant et al. 2001). The extent to which structure improvements may occur is dependent on the degree of intensification, especially the degree of pasture growth optimisation including the extent of irrigation and fertilisation.

In summary, animal treading generally reduces pore space and infiltration while increasing bulk density. The detrimental effects of soil treading damage may last for many months depending on circumstances. Although many studies have investigated single intensive treading events at various treading rates, often in wet winter conditions causing poaching and pugging damage to soils, there are few studies examining the effects of animal treading during other seasons, when the soil is unlikely to have been damaged to the same extent.

\section{Simulated compaction and treading}

Simulation studies of treading and compaction on plant yield are discussed in this section, as such studies are useful to minimise the direct plant damage during treading. In field studies of the consequences of animal treading on pastoral grazing systems, it is difficult to separate the direct effects of plant burying, crushing, bruising, and injury from that of the change in soil physical conditions. Simulated treading or compaction in a controlled environment has been used to attempt to minimise these effects.

\section{Simulated treading on seedlings}

Several studies have investigated the effects of simulated compaction on seedlings. For example, pot trials with repacked soil and perennial ryegrass (Lolium perenne) seedlings determined that plant growth was reduced when soil density was increased, which was associated with reduced soil aeration (Gradwell 1965). Soil pores $>60 \mu \mathrm{m}$ were associated with optimum growth and were $6-10 \%$ of soil volume, depending on the study. In another study, Manawa ryegrass (Lolium multiflorum $\times$ perenne cv. Manawa) and Ruanui ryegrass (Lolium perenne) seedlings up to 65 days old were grown in repacked soil compacted with a hydraulic press (Brown and Evans 1973). Herbage yields were not significantly different between treatments, but moderate compaction caused significant increases in crown and root weights. Artificial hooves have also been used in rangeland studies (Dadkhah and Gifford 1980), and short-term seedling studies up to 85 days (Sun 1990), but were confined to boxes or glasshouse pots. Resistance of Bermudagrass (Cynodon dactylon) and perennial ryegrass (Lolium perenne) to trampling was found to increase with seedling age (Sun 1990).

\section{Simulating treading and compaction}

Gradwell (1974) developed a simulated compaction procedure and used a penetrometer to test the susceptibility of several soils to compaction, and concluded that soil resistance to penetration was not a good indicator of the relative abilities of soils to resist pugging, but the latter was better predicted from the content of macropores remaining after simulated trampling.

A reduction in macroporosity caused by treading, for 3 soil types, was reported by Climo and Richardson (1984), but its magnitude depended on texture, drainage status, and the soil susceptibility to damage. The field site had been artificially compacted using a steel rod apparatus to simulate compaction. However, prior to compaction, the top $10 \mathrm{~mm}$ of soil had been removed to remove the vegetative cover. The vegetative cover, though, is likely to be important and may offer some protection to the soil structure from treading (Betteridge et al. 1999). Protective vegetative cover was also shown by Eldridge (1998) to be important. Simulated sheep trampling under low moisture conditions on monolith lysimeters collected from semi-arid grazing land increased erosion and bare ground and resulted in the loss of protective microphytic (lichen and moss) crusts (Eldridge 1998). Damage was mainly in the surface few $\mathrm{mm}$ of soil (Eldridge 1998). However, in rangelands, such micro-morphological changes have a major effect on vegetation distribution and infiltration (Greene and Ringrose-Voase 1994).

Simulated cattle-hoof treading (Di et al. 2001) can be used to avoid direct damage to temperate climate ryegrass pasture. Simulated treading, over a range of seasons, has been used to determine perennial ryegrass (Lolium perenne $\mathrm{cv}$. Yatsyn 1) relative yield relationships with soil physical condition (see later section) and impacts of several rates of simulated treading (Drewry et al. 2001). By minimising pugging damage to a Wakanui silt loam (Mollic Haplaquept), the study demonstrated that total pasture yield was reduced by a mean of $14 \%$ in the greatest simulated treading density treatment, compared with untreaded controls, during the 11 months of the trial. Macroporosity, for example, was reduced at $0-50 \mathrm{~mm}$ from $20.5 \%$ in the untreaded treatment to $10.7 \%$ in the highest simulated treading density treatment, and from $13 \%$ in the untreaded treatment to $9.3 \%$ at $50-100 \mathrm{~mm}$ in the highest simulated treading density treatment (Drewry et al. 2001).

Of note is that simulated cattle-hoof treading is considered an important tool to simulate actual cattle treading (Di et al. 2001), and thereby avoid likely natural rejuvenation of soil physical properties after treading ceases following animal exclusion (Drewry 2006). The cow-hoof treading simulator has therefore been used to simulate cattle treading pressure when walking (i.e. $220 \mathrm{kPa}$ ) in soil-pasture monolith lysimeters 
evaluating nutrient leaching and nitrous oxide emission in order to maintain soil physical conditions as they would occur under grazing (e.g. Di and Cameron 2002).

Red clover (Trifolium pratense) that was not treaded had $30 \%$ greater yield and the soil had $25 \%$ lower bulk density than a plant-soil simulated treading treatment (Moore and Laidlaw 1980). Moore and Laidlaw (1980) concluded that the indirect effect of soil compaction was as detrimental to red clover growth as the direct effect of plant damage.

For simulated trampling under woodland in Italy, Ferrero (1991) also demonstrated reduced perennial ryegrass (Lolium perenne) growth compared with a non-trampled control. Lolium perenne yield 80 days after sowing decreased by $30 \%$, but only in the most compacted plots, and it was much less sensitive to compaction than timothy (Phleum pratense) (Ferrero 1991). An average yield reduction of $14 \%$ was demonstrated for Kentucky bluegrass (Poa pratenis) and redtop (Agrostis stolonifera) grasses by simulating cattle treading (Clary 1995), a similar reduction to the perennial ryegrass yield reduction from simulated cattle treading treatments of Drewry et al. (2001). The primary compaction effect occurred during spring (Clary 1995).

\section{Simulated poaching and treading}

In a study of simulated poaching, Edmond (1958) indicated Manawa ryegrass (Lolium multiflorum $\times$ perenne) yields were reduced by $27 \%$ on poached treatments compared with nonpoached. However, artificial compaction of poached treatments 3 weeks after poaching increased yields, possibly due to breaking up the surface cap leading to increased permeability and diffusion of air. Gradwell (1965) conducted a pot trial with poached and non-poached treatments. Ryegrass seedling weights were significantly greater in non-poached compared with poached treatments, while the content of air pores $>60 \mu \mathrm{m}$ in the top $40 \mathrm{~mm}$ of soil was $10.8 \%$ in the non-poached and $2 \%$ in the poached treatment. Scholefield and Hall (1985, 1986) developed a spring-mounted pivoting penetrometer to simulate stresses exerted by a walking cow. Deformation produced by the penetrometer was demonstrated to be small and independent of water content on both sandy and clay loams. However, they concluded that deep hoof prints occur after a progressive loss of soil strength due to repeated treading.

Simulated trampling detached $15-25 \%$ of blue grama (Boureloua grucifis) and western wheatgrass (Agropyron smifhii) plant material as a result of hoof action during a 1-month study (Abdel-Magid et al. 1987). Simulated trampling was applied to small soil cores for 3 moisture regimes using a mould of a steer hoof (Abdel-Magid et al. 1987).

In summary, many studies have shown detrimental effects of simulated compaction or treading on pasture seedling production, but there appear to be few studies on mature pasture yield responses, particularly in field situations, and evaluating soil layers deeper than the surface. There is also a need to examine physical properties in deeper soil layers, and to establish relationships between pasture growth and the compaction component, without the confounding effects of animal grazing and soil pugging.

\section{Soil physical properties and plant productivity: effects and yield response curves}

Effect of macroporosity and air-filled porosity on plant productivity

As mentioned in the Introduction, research for cropping systems relating yield to soil compaction is also reviewed where appropriate. There has been research for cropping systems on the relationships between macroporosity and/or air-filled porosity and plant growth. As discussed earlier above, macroporosity and air-filled porosity can be considered as equivalent terms. Although various measures of air-filled pore space may vary with season and rainfall occurrence, they nevertheless can be considered somewhat equivalent if measured at standard matric potentials (Cameron and Buchan 2006).

Macroporosity and air-filled porosity values of $<10 \%$ are often used to indicate limiting conditions for soil aeration and plant health (Gradwell 1965; Grable 1971; Cannell 1977; Carter 1988; Lipiec and Hatano 2003). Grable (1971) reviewed the effects of soil compaction on the content, composition, and transmission of soil air, including air-filled porosity, air permeability, and diffusivity of gases. Grable (1971) indicated that diffusivity of gases was almost zero at $\sim 10 \%$ air-filled porosity. However, the critical level of air-filled porosity could be as high as $20 \%$ even at shallow depths if temperature and microbial activity are great. Similarly, the critical air-filled porosity for crop root growth was shown to be $14.5 \%$ (Hodgson and MacLeod 1989). At air-filled porosities $<14.5 \%$, gas was not able to diffuse through the pores, and was thought to be due to closed pores in the fine-textured (Typic Pellustert) soil (Hodgson and MacLeod 1989). This exceeds the previously accepted limit of 10\% (Hodgson and MacLeod 1989).

For British soils, estimates of minimum air-filled porosities for adequate diffusion and crop growth are 10-12\% (Greenwood 1971, 1975; O'Connell 1975). Above these values the oxygen content of the near-surface soil atmosphere will be similar to that in air.

Carter (1988) indicated that macroporosity should be $>14 \%$ to maintain optimum air space for cereal growth. Carter (1988) indicated that $8-10 \%$ macroporosity would maintain adequate soil water permeability for cereal growth. Macropores were defined in that study as $>50 \mu \mathrm{m}$ diameter. However, optimum macropore volumes depend on moisture content, as measured by relative saturation, to prevent root rot in cereals (Carter and Johnston 1989). At field moisture content near field capacity (e.g. $27.5 \% \mathrm{~kg} / \mathrm{kg}$ ), a macropore volume of $15.5 \%$ was required to achieve a relative saturation for adequate growth (Carter and Johnston 1989).

The continuity of air-filled pores to the soil surface is likely to be broken when air-filled pore space is less than about $10 \%$, but this value is affected by the arrangement and continuity of pores (Cannell 1977). Gas transport through soil occurs either 
by mass flow or diffusion. Gas diffusion is an important process (Stepniewski et al. 1994), although not commonly measured. Diffusivity, for example, can be expressed as the relative diffusion coefficient, $\mathrm{D} / \mathrm{D}_{\mathrm{o}}$, where $\mathrm{D}_{\mathrm{o}}$ is the coefficient of the same gas in free atmosphere at the same conditions of temperature and pressure (Stepniewski et al. 1994). The relative diffusion coefficient is useful as it is insensitive to pore diameter and can be used to derive indices of pore continuity (Ball et al. 1991; Stepniewski et al. 1994). Ball et al. (1987) concluded that relative diffusivity was useful to determine the water potential and bulk density at which aeration may limit plant growth.

A relationship between air-filled pore space and sugar beet (Beta vulgaris) yield was shown by Erikson (1982). Below 8-10\% air-filled pore space, yield was considerably reduced, but remained relatively constant from 10 to $23 \%$ air-filled pore space (Erikson 1982). Graham et al. (1986) indicated reduced wheat (Triticum aestivum cv. Avalon) root growth in soil with 5\% macroporosity, which may have been related to reduced oxygen supply. Optimum and minimum macroporosity and air-filled porosity values from the literature are shown in Table 5. Optimum values correspond to the greatest crop yield. Minimum or critical values generally represent limiting conditions for crop growth. Grevers and de Jong (1990) using image analysis also associated greater pasture yield with greater macropore area and length. Similar research is warranted to evaluate soil physical relationships with yield in permanent non-pugged pasture-grazing systems.

\section{Effect of bulk density on plant productivity}

Bulk density and penetration resistance have been shown to be poor indicators of how compaction will influence crop growth (Lindstrom and Voorhees 1994). However, the concept of relative compaction is closely related to macroporosity and crop yield (Carter 1990; Lindstrom and Voorhees 1994). Relative compaction can be obtained by dividing the measured bulk density by the maximum bulk density, such as measured by the Proctor test. Carter (1990) established a relationship between relative compaction and relative grain yield of the cereals spring barley (Hordeum vulgare) and spring wheat (Triticum aestivum) shown in Fig. 2. A macroporosity range of $12-14 \%$ was identified by Carter (1990) from the same study as adequate for soil aeration. This macroporosity range corresponded to $83-86 \%$ relative compaction. A range of $77.5-84 \%$ relative compaction was associated with a relative grain yield of $95 \%$ or greater. There were marked decreases in relative grain yield as relative compaction exceeded 84\%, corresponding to $13.5 \%$ macroporosity (Carter 1990). Similar relative measures of bulk density, such as 'degree of compactness', are useful for representing critical mechanical impedance and air-filled porosity as a function of the extent of compaction and matric water potential (Lipiec and Hakansson 2000). Using this concept rather than values of bulk density and porosity, the critical values of penetration resistance at matric suctions in the dry range and air-filled porosity in the wetter range were demonstrated by Lipiec and Hakansson (2000) to be similar between the cropped soils, irrespective of large differences in texture, porosity, and water-holding properties. Similarly, Braunack (1999) showed maximum sugarcane (Saccharum officinarum) yield occurred at an optimum degree of compactness of approximately 90\%. Braunack (1999) noted that this optimum degree of compactness differed from that of barley, wheat, and other grasses. Yield was reduced at a degree of compactness of $75-80 \%$ and $>100 \%$. A degree of compactness value can be $>100 \%$ in field trials because maximum density is measured under standard conditions. Evaluation of optimum measures of compactness is therefore needed over a range of conditions for crops and pastures.

The effects of soil compaction on root growth have been reviewed by Unger and Kaspar (1994). They indicated that compact zones with high bulk density may restrict root penetration and radial growth of roots, limit nutrient availability and aeration, increase waterlogging, and so may reduce yield. Compact layers may also

Table 5. Optimum and minimum macroporosity and air-filled porosity values for crop and pasture yield response

\begin{tabular}{llcc}
\hline Reference & Condition & Macroporosity (\%) & Crop \\
\hline Gradwell (1965) & Optimum & $6-10$ & $\begin{array}{c}\text { Perennial ryegrass (Lolium perenne) } \\
\text { seedlings } \\
\text { Barley (Hordeum vulgare), wheat } \\
\text { (Triticum aestivum) }\end{array}$ \\
Carter (1990) & Optimum & $>14$ & Barley (Hordeum vulgare), wheat \\
& Adequate & $10-12$ & (Triticum aestivum) \\
Drewry and Paton (2000) & $97 \%$ RY & & Perennial ryegrass (Lolium perenne) \\
Drewry et al. (2001) & Optimum & $11.5-11.7$ & Perennial ryegrass (Lolium perenne) \\
& & $16-17$ & Cotton (Gossypium hirsutum) \\
Hodgson and MacLeod (1989) & Minimum & Air-filled porosity (\%) & Various \\
Grable (1971) & Minimum & 14.5 & Various \\
Greenwood (1975) & Minimum & 10 or more & Various \\
O'Connell (1975) & Minimum & $10-12$ & Sugar beet (Beta vulgaris) \\
Erikson (1982) & Minimum & $8-10$ & Maize (Zea mays) \\
Stepniewski et al. (1994) & Lower limit & $5-8$ & Maize (Zea mays) \\
Stepniewski et al. (1994) & Upper limit & $15-20$ &
\end{tabular}




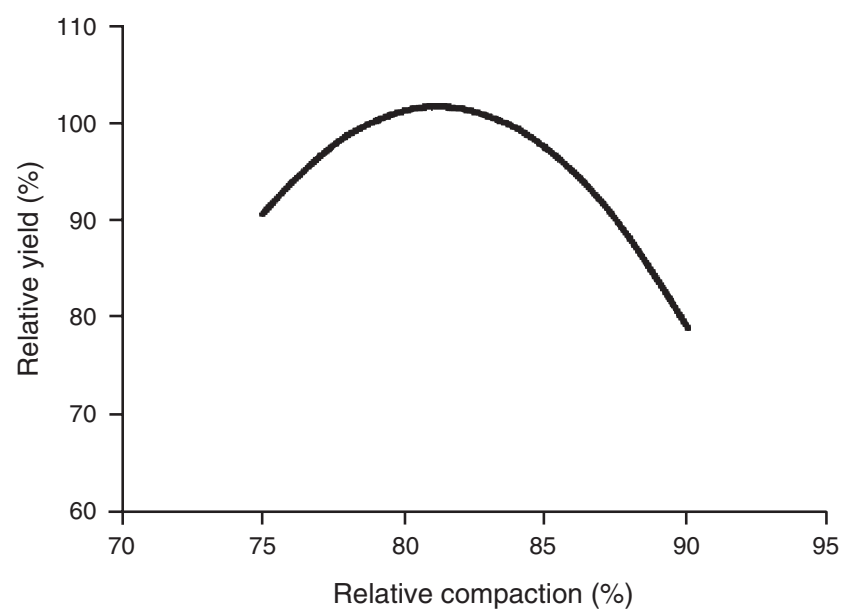

Fig. 2. Relationship between relative compaction (\%) and relative yield (\%) of cereals (adapted from Carter 1990).

limit water infiltration and hence water storage. Reducing the effects of previous compaction by ploughing resulted in increased infiltration and water storage in cotton fields. Ploughing also resulted in greater cotton (Gossypium hirsutum) yields in dry years, but yields were not affected in years with adequate rainfall. The long-term influence of management on development of critical soil properties that influence yield should be considered in cropping systems.

There is considerable literature indicating negative relationships between bulk density and crop yields (e.g. Kayombo and Lal 1994). In pot trials, Stirzaker et al. (1996) indicated that barley (Hordeum vulgare) shoot dry weight was $26 \%$ lower at $1.78 \mathrm{Mg} / \mathrm{m}^{3}$ bulk density than at $1.64 \mathrm{Mg} / \mathrm{m}^{3}$. However, barley shoot dry weight was only $3 \%$ less at the high bulk density when natural biopores existed from previous ryegrass growth, allowing deeper root access. Stirzaker et al. (1996) also found shoot yield of peas (Pisum sativum) was 75\%, and root length $57 \%$, at $1.70 \mathrm{Mg} / \mathrm{m}^{3}$, compared with their values at an optimum bulk density of $1.47 \mathrm{Mg} / \mathrm{m}^{3}$. Similarly, other studies have shown negative linear growth relationships with bulk density for shoot biomass (Mapfumo et al. 1998) and maize (Zea mays) yield (Canarache et al. 1984). Mapfumo et al. (1998) showed the most sensitive parameter for smooth bromegrass (Bromus inermis) response to compaction, as measured by bulk density, was shoot biomass.
Effect of soil structure and mechanical impedance on plant productivity

The ability of the plant root to find space in which to grow or force its way through the soil is an important factor limiting plant growth. Although the percentage of fine roots is highly variable (Boot and Mensink 1990), transmission pores are an important pathway for many growing roots. Mechanical impedance will inhibit root growth by reducing pores and affects root elongation and soil aeration, but depends on soil conditions, plant species, and the stage of plant development. Glinski and Lipiec (1990) reviewed the literature, describing reduced crop root growth with increased mechanical impedance, some of which is summarised in Table 6, showing considerable variation between crops and soils.

Ryegrass (Lolium perenne), browntop (Agrostis capillaris), and white clover (Trifolium repens) seedlings grown for 23 days in cylinders, repacked to penetration resistances of $0.25,1.40$, and 2.30 MPa, were studied by Cook et al. (1996). Shoot and root dry weights were significantly reduced with increasing penetration resistance, particularly in the $2.30 \mathrm{MPa}$ treatment. Increased impedance also reduced root growth and length. The ratio between roots and shoots remained constant as impedance increased, implying some signalling that kept root and shoot growth in synchrony (Cook et al. 1996).

Indirect effects of soil physical properties on plant productivity

Soil physical properties can also indirectly affect plant growth. For example, Letey (1985) described the effect of bulk density, texture, and pore sizes on crop yield as being an indirect effect. Their relationship with crop yield is through their effect on water, aeration, oxygen supply, temperature, and mechanical resistance. For example, reduced tomato growth at high bulk density may be caused by restricted oxygen supply, rather than just mechanical resistance. Reduced aeration may also lead to anaerobic conditions, affecting root growth through changes in respiration and nutrient uptake (Cannell 1977). Letey (1985) also suggests that the relationship between yield and soil physical conditions depends on several variables including differing plant species response, phases of growth, and interaction with climate.

Climatic variations between growing seasons may mean that crop response curves vary considerably (Boone 1986). For example, in a dry location the optimum bulk density is

Table 6. Soil mechanical impedance causing reduction in root growth (Glinski and Lipiec 1990)

\begin{tabular}{llcl}
\hline Plant & $\begin{array}{l}\text { Degree of } \\
\text { reduction }\end{array}$ & $\begin{array}{c}\text { Critical mechanical } \\
\text { impedance (MPa) }\end{array}$ & Soil texture \\
\hline Maize (Zea mays) & $50 \%$ & $0.9-1.6$ & Sandy loam \\
Barley (Hordeum vulgare) & $50 \%$ & $1.3-3.7$ & Sandy clay loam \\
Cotton (Gossypium hirsutum) & Stopped & 2.5 & Loam \\
Peas (Pisum sativum) & Stopped & 3 & Clay \\
Oats (Avena sativa) & Stopped & $4.6-5.1$ & Silt \\
Maize (Zea mays) & $50 \%$ & 5 & Loam \\
Italian ryegrass (Lolium multiflorum) & Restricted & $2-3.5$ & Various \\
Perennial ryegrass (Lolium perenne) & $80 \%$ & 8 & Loam \\
\hline
\end{tabular}


higher than for more humid regions, as water can be conserved better in dry periods (McKyes 1989). The converse is true in wet conditions, where moisture is more than adequate to support plant growth and a loose structure aids drainage and prevents water-logging. McKyes (1989) showed for corn (Zea mays) grown in a clay soil that, in a wet year, the optimum bulk density was $0.99 \mathrm{Mg} / \mathrm{m}^{3}$, whereas in relatively dry years the optimum density was about $1.13 \mathrm{Mg} / \mathrm{m}^{3}$ (Fig. 3). Optimum soil density values were larger in a sandy loam than a clay soil, due to the greater natural density of the sandy loam (McKyes 1989).

Numerous studies have established approximate limiting or optimum conditions for soil parameters including macroporosity, air-filled porosity, bulk density, and mechanical impedance. Research shows well-defined relationships between crop yield and soil physical properties. However, many of these studies relate to crops that may have a different tolerance to soil physical conditions compared with established pasture.

\section{Effects of soil physical properties on ryegrass pasture productivity}

The effects of treading-induced compaction on ryegrass pasture productivity are presented in this section. Earlier, we discussed pasture productivity when treading-induced pugging damage to soil occurred in wet conditions with high stocking rates. This section presents results for non-pugged soil conditions which are likely to occur in soil that is not as wet, and has lower stocking rates than under conditions of greater risk of pugging.

Soil compaction and ryegrass pasture productivity under non-treaded conditions

It has been suggested (Cannell 1977; Houlbrooke et al. 1997) that bulk densities from 1.3 to $1.7 \mathrm{Mg} / \mathrm{m}^{3}$ may limit root growth and plant yield. Houlbrooke et al. (1997) grew ryegrass (Lolium

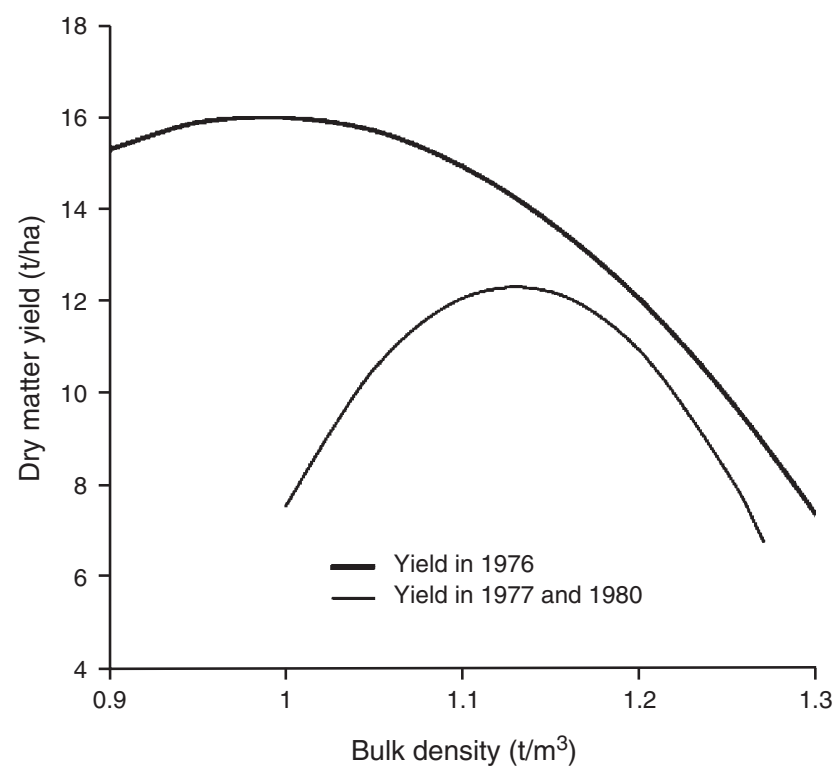

Fig. 3. Silage corn yields and soil dry bulk density in different years on a clay soil with different degrees of compaction. 1976 wet year; 1977 and 1980 were dry years (adapted from McKyes 1989). perenne) in pots containing volcanic soil in layers of varying density. Herbage yields decreased by $50 \%$ (during 171 days) as bulk density increased from 0.9 to $1.2 \mathrm{Mg} / \mathrm{m}^{3}$, beneath the germination depth. Houlbrooke et al. (1997) reported that adverse effects on ryegrass root growth and yield occurred at lower bulk densities $\left(<1.3 \mathrm{Mg} / \mathrm{m}^{3}\right)$ in their study than is commonly reported in the literature. However, air-filled porosity was $17-38 \%$ in the treatments, so air-filled porosity per se may not have been limiting to ryegrass growth. Houlbrooke et al. (1997) concluded that adverse effects were possibly due to the volcanic nature of the soil. It should be noted that although bulk density $>1.2 \mathrm{Mg} / \mathrm{m}^{3}$ was considered compact in this volcanic soil, such densities are commonly considered non-compact in most mineral and sedimentary soils.

Perennial ryegrass (Lolium perenne) pasture in Scotland, compacted by wheeled traffic, yielded $68 \%$ compared with a zero compaction control (Douglas and Crawford 1991). Douglas and Crawford (1993) reported reduced macroporosity, air permeability, and infiltration when ryegrass pasture had been subjected to compaction by wheeled or mechanical traffic. Yield reduction was particularly severe when the volume of air-filled pores at $20-70 \mathrm{~mm}$ was $<4 \%$, indicating poor aeration. Douglas (1994) reviewed traffic-induced compaction in European forage pasture. He concluded that productivity decline was through deterioration in bulk density or air-filled porosity. This is illustrated by the comparison of traffic systems in Fig. 4, demonstrating yields of ryegrass (Lolium perenne) were greatest when soil macropore volume was greatest. Macropores in that study were defined as pores $>195 \mu \mathrm{m}$ diameter (Koppi et al. 1992).

In a field trial to evaluate effects of soil physical characteristics on perennial ryegrass (Lolium perenne cv. Yatsyn 1) yield, Drewry et al. (2001) used simulated cattlehoof treading (Di et al. 2001) to avoid direct damage to ryegrass pasture. The study avoided any pugging and minimised pasture damage common with grazing on a Pallic soil (Mollic Haplaquept), commonly considered susceptible to treading damage. Of the soil physical properties measured,

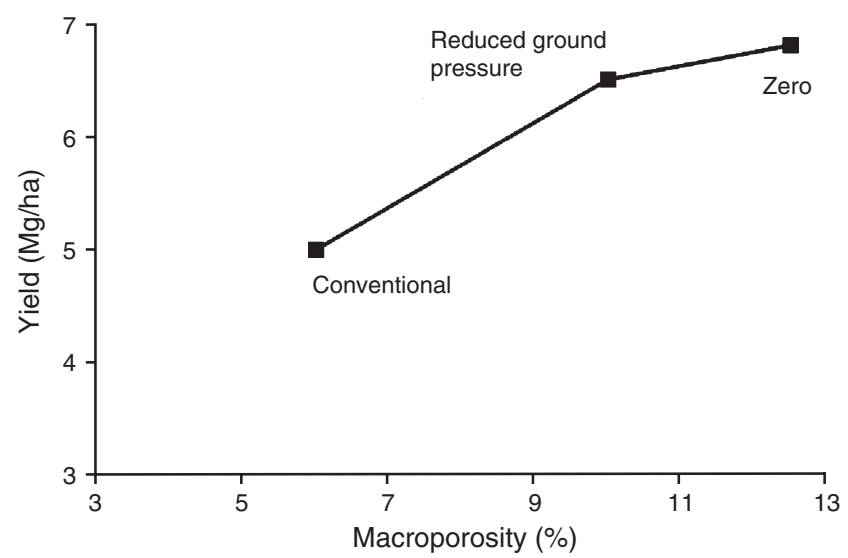

Fig. 4. First-cut ryegrass yield from three traffic systems (conventional traffic, reduced ground pressure traffic and zero traffic), averaged over 4 years, and soil macroporosity (pores $>195 \mu \mathrm{m}, \%$ ) at 50-100 mm (adapted from Douglas 1994). 
macroporosity gave the strongest relationship with ryegrass relative yield. There was a significant relationship between relative pasture yield and macroporosity at $0-50 \mathrm{~mm}$ depth, with optimum macroporosity being 16-17\% (Drewry et al. 2001; Fig. 5). The soil physical property-yield relationships in that study were of a similar nature to some that have been presented for crops (Negi et al. 1981; McKyes 1989; Carter 1990), with linear relationships having also been reported (Pabin et al. 1991; Kayombo and Lal 1994). Some crop response curves may undergo a 'lateral shift' (Fig. 3) depending on wet or dry years or different textures (Negi et al. 1981; McKyes 1989).

\section{Soil compaction and ryegrass pasture productivity under treading}

This section discusses several studies to evaluate yield from treading-induced compacted soil (i.e. avoiding soil pugging damage), or where yield relationship curves are developed when pugging does not occur.

Annual pasture yield was depressed by $7 \%$ for grazed (48 cows/ha.day) $v$. non-grazed pasture treatments, on a $\mathrm{Te}$ Kowhai silt loam (Typic Ochraqualf; Campbell 1966) in the Waikato. However, treatment yield differences were not great in any of the 3 years. Kelly (1985) showed similar reductions in yield (Table 7), and declines in air-filled porosity (Table 4).

Several studies have demonstrated macroporosity or airfilled porosity to be a good indicator of pasture yield (Grevers and de Jong 1990; Drewry and Paton 2000). Drewry and Paton (2000) indicated that various soils under cattle grazing had an average macroporosity of about $8 \%$, which was associated with $81 \%$ of maximum pasture yield. However, they indicated that the relationship between yield and macroporosity varied between soil types. Relationships between macroporosity and pasture relative yield over 2 years indicated that at $97 \%$ relative pasture yield, the average level of macroporosity (averaged over $0-0.20 \mathrm{~m}$ depth) in 3 silt loams (Typic Fragiaquept, Typic and Aquic Dystrudepts) was 11.5-11.7\%. Similarly, a relationship was developed for second year results, where

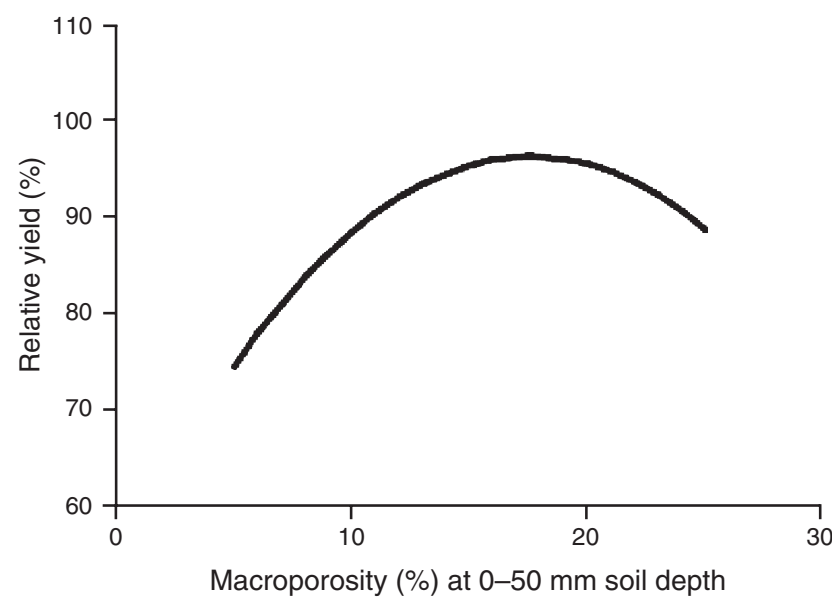

Fig. 5. Relationship between relative ryegrass pasture yield (\%) during summer and macroporosity ( $\%$ pores $>30 \mu \mathrm{m})$. Adapted from Drewry et al. (2001). macroporosity (averaged over $0-0.20 \mathrm{~m}$ depth) was $10.8 \%$ at $97 \%$ relative pasture yield (Drewry and Paton 2000). Although optimum or a critical macroporosity was not determined, a relative pasture yield of $95-97 \%$ is commonly used for near maximum relative yield, in pasture nutrient relationships (Drewry and Paton 2000). Other details for the studies are shown in Table 7.

Linear relationships between soil physical properties and yield responses for 7 years of dairy grazing trials were determined by Drewry et al. (2004a). Soil physical properties at both $0-50$ and $50-100 \mathrm{~mm}$ depths showed positive relationships with relative pasture yield in spring, with the best fit being for macroporosity (Drewry et al. $2004 a$ ). The study showed macroporosities at 0-50 and $50-100 \mathrm{~mm}$ were the most useful indicators for predicting spring and summer/autumn pasture yields, but there were no reliable physical indicators for annual pasture yield (Drewry et al. 2004a). Although individual sites varied, the most responsive relationship was for a Pallic soil (Aeric Fragiaquept) site during year 1 . Across all sites, at $0-50 \mathrm{~mm}$, a unit (i.e. 1\%) increase in macroporosity was associated with a $1.6 \%$ increase in spring relative yield. At $50-100 \mathrm{~mm}$, a unit increase in macroporosity was associated with a $2.6 \%$ increase in spring relative yield (Drewry et al. 2004a). There were also negative response relationships for summer/autumn yield and soil physical properties, possibly related to an improvement in physical condition. Similarly, the response curves highlighted in other sections demonstrate that at some parts of the yield response function, responses can be negative.

Confounding influences in such examples help illustrate the incomplete knowledge of factors influencing yield and soil physical properties, and hence the need for further research. A contributing factor to the results in the study of Drewry et al. $(2004 a)$ is likely to have been the soil physical condition at the Pallic soil site following a cycle of natural recovery during summer/autumn, after compaction had occurred during the wetter spring periods (Drewry et al. 2004b; Drewry 2006). It is likely that such soil recovery changes could occur elsewhere, particularly when soil undergoes wetting and drying cycles. This information would be beneficial to provide more certainty in decision support tools or models of pasture growth with soil physical conditions to better provide economic evaluation of management strategies.

\section{Tools and management of soil physical condition and pasture yields on-farm}

Information on pastoral yield responses to soil physical condition would be beneficial to provide information for decision support tools, or appropriate models to better provide economic evaluation of management strategies such as feed-pads or on-off grazing. In regions where dairy farming is currently expanding (e.g. Monaghan et al. 2006), soil management or farm system tools and yield response information are required for land managers for improved farm system cost-benefit analyses. Such tools will help land managers balance unfavourable aspects with improvements in organic matter and fertility that may occur through greater farming inputs and development. In the small number of studies 


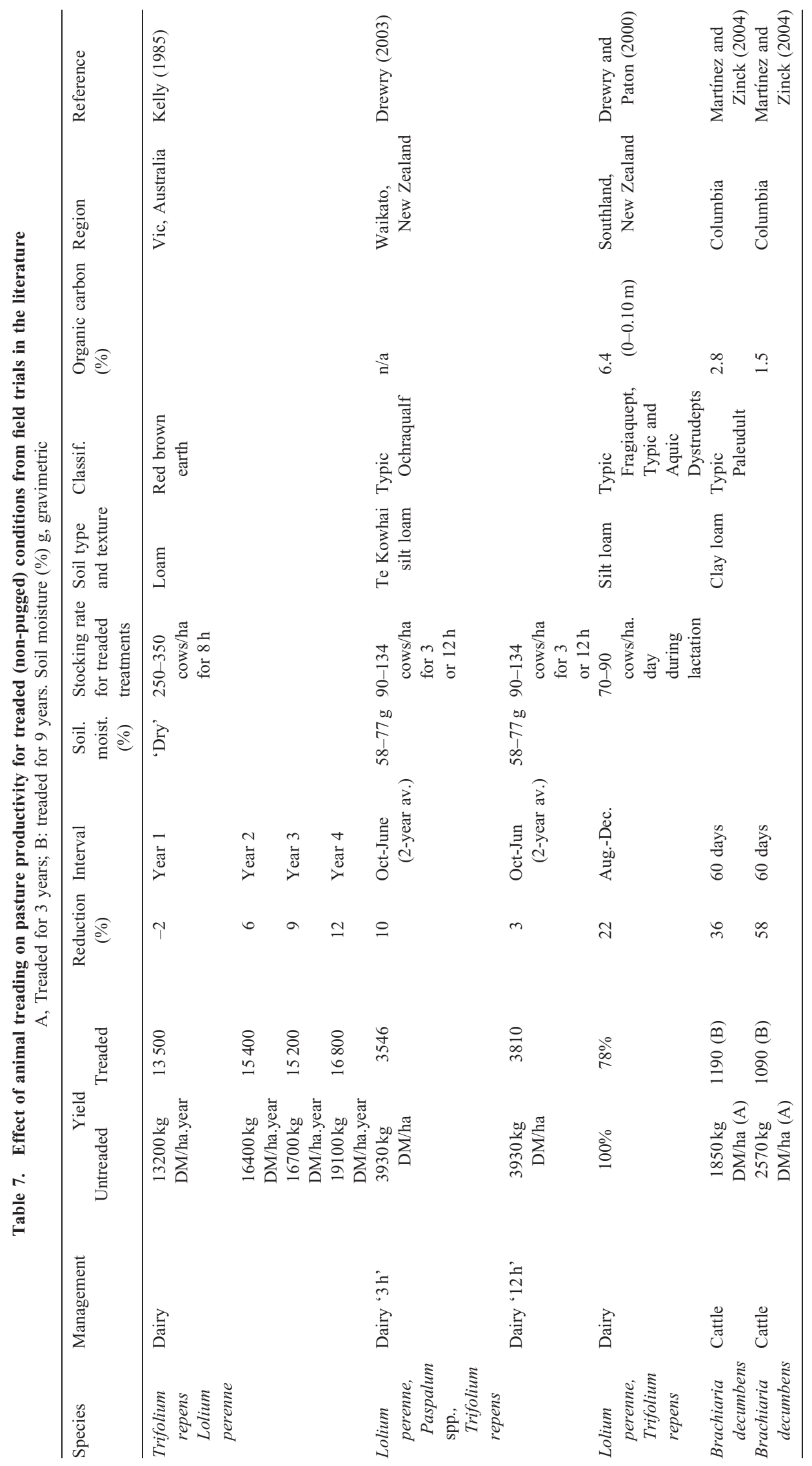


that have examined pastoral response relationships across a wide range of soil physical properties, few have defined the critical or optimal soil physical values associated with maximum pasture yield. Information on soil physical values associated with optimum pasture yield would add value when integrated into tools for land managers to enable them to make informed decisions about soil management.

Recent efforts to provide practical tools for farmer decisionmaking relating to soil physical condition include a simple penetrometer for on-off grazing for on-the-spot decisions (Betteridge et al. 2003; Zegwaard 2006) and a simple readyreckoner (look-up chart) for grazing decisions (Betteridge et al. 2003). When, for example, $\geq 50 \%$ of soil indentations using the penetrometer are $\geq 20 \mathrm{~mm}$ depth, a grazing with $300 \mathrm{cows} / \mathrm{ha}$ for $3 \mathrm{~h}$ is likely to result in pasture yield decline (Zegwaard 2006).

Tools for long-term soil quality monitoring range from Visual Soil Assessment guides (Shepherd 2003), a Soil Quality Management System for cropping soil systems (Beare et al. 2003), to all-encompassing paddock or wholefarm systems such as the Dairy Soil Management System (de Klein et al. 2004). The last also contained recommendations for monitoring soil quality indicators such as macroporosity. Such systems are very useful for farmers and farm consultants to gain knowledge of soil quality on-farm and include a wide range of indicators. Alternatively, the combined effects of integrating penetration resistance, macroporosity (air-filled porosity), and matric potential could be further evaluated by the 'least limiting water range' concept (e.g. Zou et al. 2000), which would be useful in a research context for future soil physical treading studies. Indeed, even in the extensive compaction-cropping literature, Lipiec and Hatano (2003) concluded that there is considerable potential to improve compaction and crop modelling research by incorporating macroporosity as input data to compaction models. Similarly, macroporosity, or readily available alternative indicators, should be included in decision support models for farm grazing systems.

\section{Conclusions}

Although the effects of soil pugging are commonly apparent, the effects of compaction from treading causes a range of undesirable effects which may not always be obvious. Increased levels of compaction can lead to reductions in crop and pasture yields, and are also associated with a degradation of soil structure and physical properties. Animal treading studies often show large reductions in pasture yield, particularly when soil is pugged in wet conditions at high stocking rates. Pasture productivity, when reduced by soil compaction only, is depressed less than for soil conditions where there is considerable surface deformation such as pugging. It is difficult to separate the effects of direct plant damage, pugging, and animal grazing from the indirect effects of changes in soil physical properties. Attempts to overcome these problems in pasture have been made in a limited number of simulated compaction or simulated treading studies. Despite response relationships between plant yield and soil physical conditions having been derived for many crops, there are few comparable relationships for grazed-pasture systems.
The review has shown that there is little information on the effects of grazing animal treading on soil physical property relationships with pastoral yield, when soil pugging and plant damage are minimised. Many simulated trampling studies have confined soil physical measurements to one surface soil layer. Evaluation of soil physical properties at incremental depths would improve our knowledge in treading studies. There is some evidence that compaction and natural recovery occur in a cycle, but research quantifying this within the same farm system is limited. Finally, and most importantly, knowledge of response curve relationships and critical or optimum soil physical values for grazing systems is required for improved soil management. Several studies reviewed showed adequate plant growth required minimum soil air-filled porosities or macroporosities greater than the commonly accepted value of $10 \%$. Soil physical and pasture yield response relationships are needed to provide improved practical and rigorously tested farm-system decision support models and tools for land managers. These tools are particularly important to enhance the ability to make informed, long-term, and economically viable decisions for management options to protect soil structure. Suitable soil physical condition indicators, such as macroporosity, or suitable surrogates should be included in future decision support tools or models for grazing conditions, particularly for farm systems.

\section{Acknowledgments}

Early parts of this work were funded by AgResearch Ltd, Lincoln University and the New Zealand Foundation for Research, Science and Technology. The authors acknowledge support of AgResearch Ltd and Lincoln University staff, particularly Jeff Morton and Liz Wedderburn during the early parts of this work. We acknowledge assistance from the Australian National University and the Cooperative Research Centre for Landscape Environments and Mineral Exploration while drafting the manuscript. Thanks to Richard Greene and Lachlan Newham from the Australian National University and to the reviewers for helpful comments that improved the manuscript. Thanks to Tom Marshall for graphic design assistance with Figure 1.

\section{References}

Abdel-Magid AH, Trlica MJ, Hart RH (1987) Soil and vegetation responses to simulated trampling. Journal of Range Management 40, 303-306. doi: $10.2307 / 3898724$

Anderson F (2004) Effects of time controlled grazing and set stocking on soil and pasture: southern and central tablelands, NSW. BSc (Hons), The Australian National University, Canberra, Australia.

Ball BC, Monnier G, Goss MJ (1987) Air permeability and gas diffusion measurements to quantify soil compaction. In 'Soil compaction and regeneration'. (A.A. Balkema: Rotterdam, The Netherlands)

Ball BC, Smith KA, Mullins CE (1991) Gas movement. In 'Soil analysis: physical methods'. pp. 511-549. (Marcel Dekker Inc.: New York)

Ball BC, Watson CA, Baddeley JA (2007) Soil physical fertility, soil structure and rooting conditions after ploughing organically managed grass/clover swards. Soil Use and Management 23, 20-27. doi: 10.1111/ j.1475-2743.2006.00059.x

Beare MH, Tregurtha CS, Lawrence EJ (2003) Quantifying the effects of management history on soil quality and crop performance using the Soil Quality Management System. In 'Tools for nutrient and pollutant management'. Palmerston North. (Eds LD Currie, JA Hanly) pp. 167-174. (Fertiliser and Lime Research Centre, Massey University: New Zealand) 
Betteridge K, Drewry J, Mackay A, Singleton P (2003) Managing treading damage on dairy and beef farms in New Zealand: booklet for farmers and industry. AgResearch Ltd, Hamilton, New Zealand.

Betteridge K, Mackay AD, Shepherd TG, Barker DJ, Budding PJ, Devantier BP, Costall DA (1999) Effect of cattle and sheep treading on surface configuration of a sedimentary hill soil. Australian Journal of Soil Research 37, 743-760.

Boone FR (1986) Towards soil compaction limits for crop growth. Netherlands Journal of Agricultural Science 34, 349-360.

Boot R, Mensink M (1990) Size and morphology of root systems of perennial grasses from contrasting habitats as affected by nitrogen supply. Plant and Soil 129, 291-299.

Braunack MV (1999) Economic cost of soil compaction. BSES Publication SRDC Final Report SD99008. Tully, Queensland.

Brown KR, Evans PS (1973) Animal treading. A review of the work of the late D. B. Edmond. New Zealand Journal of Agricultural Research 1, 217-226.

Cameron KC, Buchan GD (2006) Porosity and pore-size distribution. In 'Encyclopedia of soil science'. (Ed. R Lal) pp. 1350-1353. (CRC Press: Boca Raton, FL)

Campbell AG (1966) Effects of treading by dairy cows on pasture production and botanical structure, on a Te Kowhai soil. New Zealand Journal of Agricultural Research 9, 1009-1024.

Canarache A, Colibas I, Colibas M, Horobeanu I, Patru V, Simota H, Trandafirescu T (1984) Effect of induced compaction by wheel traffic on soil physical properties and yield of maize in Romania. Soil and Tillage Research 4, 199-213. doi: 10.1016/0167-1987(84)90048-5

Cannell RQ (1977) Soil aeration and compaction in relation to root growth and soil management. Applied Biology 2, 1-86.

Carter MR (1988) Temporal variability of soil macroporosity in a fine sandy loam under mouldboard ploughing and direct drilling. Soil and Tillage Research 12, 37-51. doi: 10.1016/0167-1987(88)90054-2

Carter MR (1990) Relative measures of soil bulk density to characterize compaction in tillage studies on fine sandy loams. Canadian Journal of Soil Science 70, 425-433.

Carter MR, Johnston HW (1989) Association of soil macroporosity and relative saturation with root rot severity of spring cereals. Plant and Soil 120, 149-152. doi: 10.1007/BF02370301

Clary WP (1995) Vegetation and soil responses to grazing simulation on riparian meadows. Journal of Range Management 48, 18-25. doi: $10.2307 / 4002499$

Clifton E (2005) Exclusion of stock from floodplain wetlands: changes in soil and vegetation characteristics, mid-Murrumbidgee region, NSW. B.Sc (Hons) thesis, The Australian National University, Australia.

Climo WJ, Richardson M (1984) Factors affecting the susceptibility of three soils in the Manawatu to stock treading. New Zealand Journal of Agricultural Research 27, 247-253.

Cluzeau D, Binet F, Vertes F, Simon JC, Riviere JM, Trehen P, Kretzschmar A (1992) Effects of intensive cattle trampling on soil-plant-earthworms system in two grassland types. Soil Biology \& Biochemistry 24, 1661-1665. doi: 10.1016/0038-0717(92)90166-U

Conant RT, Paustian K, Elliott ET (2001) Grassland management and conversion into grassland: effects on soil carbon. Ecological Applications 11, 343-355. doi: 10.1890/1051-0761(2001)011[0343: GMACIG]2.0.CO;2

Cook A, Marriott CA, Seel W, Mullins CE (1996) Effects of mechanical impedance on root and shoot growth of Lolium perenne L., Agrostis capillaris and Trifolium repens L. Journal of Experimental Botany 47, 1075-1084. doi: 10.1093/jxb/47.8.1075

Curll ML, Wilkins RJ (1983) The comparative effects of defoliation, treading and excreta on a Lolium perenne-Trifolium repens pasture grazed by sheep. Journal of Agricultural Science 100, $451-460$.
Dadkhah M, Gifford GF (1980) Influence of vegetation, rock cover, and trampling on infiltration rates and sediment production. Water Resources Bulletin 16, 979-986.

de Klein CAM, Tarbotton I, Morton J, Betteridge K, Beare M, Officer S, Tregurtha CS, Thomson B (2004) Best management practice for grazing dairy cows: using the Dairy Soil Management System. AgResearch Ltd and Crop and Food Research, Hamilton, New Zealand.

Di HJ, Cameron KC (2002) The use of a nitrification inhibitor, dicyandiamide (DCD), to decrease nitrate leaching and nitrous oxide emissions in a simulated grazed and irrigated grassland. Soil Use and Management 18, 395-403. doi: 10.1079/ SUM2002151

Di HJ, Cameron KC, Milne J, Drewry JJ, Smith NP, Hendry T, Moore S, Reijnen B (2001) A mechanical hoof for simulating animal treading under controlled conditions. New Zealand Journal of Agricultural Research 44, 111-116.

Douglas JT (1994) Responses of perennial forage crops to soil compaction. In 'Soil compaction in crop production'. (Eds BD Soane, C van Ouwerkerk) pp. 343-364. (Elsevier Science Publishers B.V.: Amsterdam, The Netherlands)

Douglas JT, Crawford CE (1991) Wheel-induced soil compaction effects on ryegrass production and nitrogen uptake. Grass and Forage Science 46, 405-416. doi: 10.1111/j.1365-2494.1991.tb02401.x

Douglas JT, Crawford CE (1993) The response of a ryegrass sward to wheel traffic and applied nitrogen. Grass and Forage Science 48, 91-100. doi: $10.1111 / j .1365-2494.1993 . t b 01841 . x$

Drewry JJ (2003) Dairy grazing strategies to minimise soil pugging and compaction in Waikato. Proceedings of the New Zealand Grassland Association 65, 99-103.

Drewry JJ (2006) Natural recovery of soil physical properties from treading damage of pastoral soils in New Zealand and Australia: a review. Agriculture Ecosystems \& Environment 114, 159-169. doi: 10.1016/ j.agee.2005.11.028

Drewry JJ, Cameron KC, Buchan GD (2001) Effect of simulated dairy cow treading on soil physical properties and ryegrass pasture yield. New Zealand Journal of Agricultural Research 44, 181-190.

Drewry JJ, Littlejohn RP, Paton RJ (2000) A survey of soil physical properties on sheep and dairy farms in southern New Zealand. New Zealand Journal of Agricultural Research 43, 251-258.

Drewry JJ, Littlejohn RP, Paton RJ, Singleton PL, Monaghan RM, Smith LC (2004a) Dairy pasture responses to soil physical properties. Australian Journal of Soil Research 42, 99-105. doi: $10.1071 /$ SR03055

Drewry JJ, Paton RJ (2000) Effects of cattle treading and natural amelioration on soil physical properties and pasture under dairy farming in Southland, New Zealand. New Zealand Journal of Agricultural Research 43, 377-386.

Drewry JJ, Paton RJ, Monaghan RM (2004b) Soil compaction and recovery cycle on a Southland dairy farm: implications for soil monitoring. Australian Journal of Soil Research 42, 851-856. doi: 10.1071/ SR03169

Earl JM, Jones CE (1996) The need for a new approach to grazing management - is cell grazing the answer? The Rangeland Journal 18, 327-350. doi: 10.1071/RJ9960327

Edmond DB (1958) Some effects of soil physical condition on ryegrass growth. New Zealand Journal of Agricultural Research 1, 652-659.

Edmond DB (1964) Some effects of sheep treading on the growth of 10 pasture species. New Zealand Journal of Agricultural Research 7, 1-16.

Eldridge DJ (1998) Trampling of microphytic crusts on calcareous soils, and its impact on erosion under rain-impacted flow. CATENA 33, 221-239. doi: 10.1016/S0341-8162(98)00075-7 
Erikson AE (1982) Tillage effects on soil aeration. In 'Predicting tillage effects on soil physical properties and processes'. ASA Special Publication 44. (Ed. PW Unger) pp. 91-104. (American Society of Agronomy: Madison, WI)

Ferrero AF (1991) Effect of compaction simulating cattle trampling on soil physical characteristics in woodland. Soil \& Tillage Research 19, 319-329. doi: 10.1016/0167-1987(91)90099-J

Glinski J, Lipiec J (1990) 'Soil conditions and plant roots.' (CRC Press: Boca Raton, FL)

Grable AR (1971) Effects of compaction on content and transmission of air in soils. In 'Compaction of agricultural soils'. (Ed. KK Barnes) (American Society of Agricultural Engineers: St. Joseph, MI)

Gradwell MW (1960) Changes in pore-space of a pasture topsoil under animal treading. New Zealand Journal of Agricultural Research 3, 663-674.

Gradwell MW (1965) Soil physical conditions of winter and the growth of ryegrass plants I. Effects of compaction and puddling. New Zealand Journal of Agricultural Research 8, 238-261.

Gradwell MW (1968) Compaction of pasture topsoils under winter grazing. In 'Transactions of the 9th International Congress of Soil Science'. pp. 429-435. (IUSS)

Gradwell MW (1974) Laboratory test methods for the structural stabilities of soils under grazing. In 'Transactions of the 10th International Congress of Soil Science'. Moscow, Vol 1. pp. 341-350. (Nauka Publishing)

Graham JP, Blackwell PS, Armstrong JV, Christian DG, Howse KR, Dawson CJ, Butler AR (1986) Compaction of a silt loam by wheeled agricultural vehicles. II. Effects on growth and yield of direct-drilled winter wheat. Soil \& Tillage Research 7, 189-203. doi: 10.1016/0167-1987(86)90463-0

Greene RSB, Kinnell PIA, Wood JT (1994) Role of plant cover and stock trampling on runoff and soil-erosion from semi-arid wooded rangelands. Australian Journal of Soil Research 32, 953-973. doi: 10.1071/ SR9940953

Greene RSB, Ringrose-Voase AJ (1994) Micromorphological and hydraulic properties of surface crusts formed on a read earth soil in the semi-arid rangelands of eastern Australia. In 'Soil micromorphology: studies in management and genesis'. (Eds AJ Ringrose-Voase, GS Humphreys) pp. 763-776. (Elsevier: Amsterdam)

Greenland DJ (1981) Soil management and soil degradation. Journal of Soil Science 32, 301-322. doi: 10.1111/j.1365-2389.1981.tb01708.x

Greenwood DJ (1971) Soil aeration and plant growth. Reports of the Progress of Applied Chemistry During 1970 55, 423-431.

Greenwood DJ (1975) Measurement of soil aeration. Ministry of Agriculture, Fisheries and Food Technical Bulletin 29, 261-272.

Greenwood KL, McKenzie BM (2001) Grazing effects on soil physical properties and the consequences for pastures: a review. Australian Journal of Experimental Agriculture 41, 1231-1250. doi: 10.1071/ EA00102

Greenwood PB, McNamara RM (1992) An analysis of the physical condition of two intensively grazed Southland soils. Proceedings of the New Zealand Grassland Association 54, 71-75.

Greenwood KL, MacLeod DA, Hutchinson KJ (1997) Long-term stocking rate effects on soil physical properties. Australian Journal of Experimental Agriculture 37, 413-419. doi: 10.1071/EA96131

Grevers MCJ, de Jong E (1990) The characterization of soil macroporosity of a clay soil under ten grasses using image analysis. Canadian Journal of Soil Science 70, 93-103.

Hamilton DT, Horne DJ (1988) The effect of treading damage on pasture utilisation and topsoil structure. In 'Proceedings of the Fourth National Land Drainage Seminar'. Palmerston North, New Zealand. (Eds DJ Horne, IFH Furkert) pp. 133-141. (Massey University: New Zealand)

Hillel D (1980) 'Fundamentals of soil physics.' (Academic Press: London)
Hodgson AS, MacLeod DA (1989) Use of oxygen density to estimate critical air-filled porosity of a Vertisol. Soil Science Society of America Journal 53, 355-361.

Horne DJ, Singleton PL (1997) Managing wet soils in wet years: a cautionary tale. Dairy Farming Annual 49, 117-124.

Houlbrooke DJ, Thom ER, Chapman R, McLay CDA (1997) A study of the effects of soil bulk density on root and shoot growth of different ryegrass lines. New Zealand Journal of Agricultural Research 40, 429-435.

Houlbrooke DJ, Morton JD, Paton RJ, Littlejohn RP (2006) The impact of land-use intensification on soil physical quality and plant yield response in the North Otago rolling downlands. Proceedings of the New Zealand Grassland Association 68, 165-172.

Kayombo B, Lal R (1994) Responses of tropical crops to soil compaction. In 'Soil compaction in crop production'. (Eds BD Soane, C van Ouwerkerk) pp. 287-316. (Elsevier Science Publishers B.V.: Amsterdam, The Netherlands)

Kelly KB (1985) Effects of soil modification and treading on pasture growth and physical properties of an irrigated red-brown earth. Australian Journal of Agricultural Research 36, 799-807. doi: 10.1071/ AR9850799

Koppi AJ, Douglas JT, Moran CJ (1992) An image analysis evaluation of soil compaction in grassland. Journal of Soil Science 43, 15-25. doi: $10.1111 / \mathrm{j} .1365-2389.1992 . t b 00116 . x$

Kurz I, O'Reilly CD, Tunney H (2006) Impact of cattle on soil physical properties and nutrient concentrations in overland flow from pasture in Ireland. Agriculture, Ecosystems \& Environment 113, 378-390. doi: 10.1016/j.agee.2005.10.004

Ledgard SF, Thom ER, Singleton PL, Thorrold BS, Edmeades DC, Lomas J (1996) Environmental impacts of dairy systems. In 'Proceedings 48th Ruakura Farmers' Conference'. New Zealand. pp. 26-33. (AgResearch: New Zealand)

Letey J (1985) Relationship between soil physical properties and crop production. Advances in Soil Science 1, 277-294.

Lindstrom MJ, Voorhees WB (1994) Responses of temperate crops in North America to soil compaction. In 'Soil compaction in crop production'. (Eds BD Soane, C van Ouwerkerk) pp. 265-286. (Elsevier Science Publishers B.V.: Amsterdam, The Netherlands)

Lipiec J, Hakansson I (2000) Influences of the degree of compactness and matric water tension on some important plant growth factors. Soil and Tillage Research 53, 87-94. doi: 10.1016/ S0167-1987(99)00094-X

Lipiec J, Hatano R (2003) Quantification of compaction effects on soil physical properties and crop growth. Geoderma 116, 107-136. doi: 10.1016/S0016-7061(03)00097-1

Lobry de Bruyn LA, Kingston TJ (1997) Effects of summer irrigation and trampling in dairy pastures on soil physical properties and earthworm number and species composition. Australian Journal of Agricultural Research 48, 1059-1079. doi: 10.1071/A94132

Mapfumo E, Chanasyk DS (1998) Guidelines for safe trafficking and cultivation, and resistance-density-moisture relations of three disturbed soils from Alberta. Soil and Tillage Research 46, 193-202. doi: 10.1016/S0167-1987(98)00100-7

Mapfumo E, Chanasyk DS, Naeth MA, Baron VS (1998) Forage growth and yield components as influenced by subsurface compaction. Agronomy Journal 90, 805-812.

Marshall TJ, Holmes JW (1988) 'Soil physics.' (Cambridge University Press: Cambridge, UK)

Martínez LJ, Zinck JA (2004) Temporal variation of soil compaction and deterioration of soil quality in pasture areas of Colombian Amazonia. Soil and Tillage Research 75, 3-18. doi: 10.1016/j.still.2002.12.001

McDowell RW, Drewry JJ, Paton RJ (2004) Effects of deer grazing and fence-line pacing on water and soil quality. Soil Use and Management 20, 302-307. doi: 10.1079/SUM2004261 
McKyes E (1989) Agricultural engineering soil mechanics. Developments in Agricultural Engineering 10, 1-292. (Elsevier: Amsterdam)

McLaren RG, Cameron KC (1996) 'Soil science: sustainable production and environmental protection.' (Oxford University Press: Auckland, New Zealand)

Menneer J, Ledgard S, McLay C, Silvester W (2001) What impact does dairy cow pugging have on clover N2 fixation and long-term farm production? Proceedings of the New Zealand Grassland Association 63, 63-67.

Menneer JC, Ledgard SF, McLay CDA, Silvester WB (2005) The effects of treading by dairy cows during wet soil conditions on white clover productivity, growth and morphology in a white clover-perennial ryegrass pasture. Grass and Forage Science 60, 46-58. doi: 10.1111/ j.1365-2494.2005.00450.x

Milne RM, Haynes RJ (2004) Comparative effects of annual and permanent dairy pastures on soil physical properties in the Tsitsikamma region of South Africa. Soil Use and Management 20, 81-88. doi: 10.1079/ SUM2003227

Monaghan RM, Wilcock RJ, Smith LC, Tikkisetty B, Thorrold BS, Costall D (2006) Linkages between land management activities and water quality in an intensively farmed catchment in southern New Zealand. Agriculture, Ecosystems \& Environment 118, 211-222. doi: 10.1016/ j.agee.2006.05.016

Moore NA, Laidlaw AS (1980) An assessment of the direct and indirect effects of simulated treading on red clover. Record of Agricultural Research 28, 81-85.

Mulholland B, Fullen MA (1991) Cattle trampling and soil compaction on loamy sands. Soil Use and Management 7, 189-193. doi: 10.1111/ j.1475-2743.1991.tb00873.x

Negi SG, McKyes E, Raghavan GSV, Taylor F (1981) Relationships of field traffic and tillage to corn yields and soil properties. Journal of Terramechanics 18, 81-90. doi: 10.1016/0022-4898(81)90002-1

Nie ZN, Ward GN, Michael AT (2001) Impact of pugging by dairy cows on pastures and indicators of pugging damage to pasture soil in southwestern Victoria. Australian Journal of Agricultural Research 52, 37-43. doi: 10.1071/AR00063

O'Connell DJ (1975) The measurement of apparent specific gravity of soils and its relationship to mechanical composition and plant root growth. Ministry of Agriculture, Fisheries and Food Technical Bulletin 29, 298-313.

Pabin J, Sienkiewicz J, Wlodek S (1991) Effect of loosening and compaction on soil physical properties and sugar beet yield. Soil and Tillage Research 19, 345-350. doi: 10.1016/0167-1987(91)90101-3

Pande TN, Valentine I, Betteridge K, Mackay A, Horne D (2000) Pasture damage and regrowth from cattle treading. Proceedings of the New Zealand Grassland Association 62, 155-160.

Pande TN, Yamamoto H (2006) Cattle treading effects on plant growth and soil stability in the mountain grassland of Japan. Land Degradation and Development 17, 419-428. doi: 10.1002/ldr.747

Scholefield D, Hall DM (1985) A method to measure the susceptibility of pasture soils to poaching by cattle. Soil Use and Management 1, 134-138. doi: 10.1111/j.1475-2743.1985.tb00976.x

Scholefield D, Hall DM (1986) A recording penetrometer to measure the strength of soil in relation to the stressed exerted by a walking cow. Journal of Soil Science 37, 165-176. doi: 10.1111/j.1365-2389.1986.tb00016.x

Scholefield D, Patto PM, Hall DM (1985) Laboratory research on the compressibility of four topsoils from grassland. Soil and Tillage Research 6, 1-16. doi: 10.1016/0167-1987(85)90002-9

Sharrow SH (2007) Soil compaction by grazing livestock in silvopastures as evidenced by changes in soil physical properties. Agroforestry Systems 71, 215-223. doi: 10.1007/s10457-007-9083-4

Shepherd TG (2003) Assessing soil quality using visual soil assessment. In 'Tools for nutrient and pollutant management'. Palmerston North. (Eds LD Currie, JA Hanly) pp. 153-166. (Fertiliser and Lime Research Centre, Massey University: New Zealand)
Singleton PL, Addison B (1999) Effects of cattle treading on physical properties of three soils used for dairy farming in the Waikato, North Island, New Zealand. Australian Journal of Soil Research 37, 891-902. doi: $10.1071 /$ SR98101

Southorn NJ, Cattle S (2004) The dynamics of soil quality in livestock grazing systems. In 'SuperSoil 2004: 3rd Australian and New Zealand Soils Conference'. Sydney. (Ed. B Singh) Published on CD-ROM. (University of Sydney: Sydney, NSW)

Sparling GP, Schipper LA, Bettjeman W, Hill R (2004) Soil quality monitoring in New Zealand: practical lessons from a 6-year trial. Agriculture Ecosystems \& Environment 104, 523-534. doi: 10.1016/ j.agee.2004.01.021

Steinfeld H, Gerber P, Wassenaar T, Castel V, Rosales M, de Haan C (2006) 'Livestock's long shadow: environmental issues and options.' (FAO: Rome)

Stephenson GR, Veigel A (1987) Recovery of compacted soil on pastures used for winter cattle feeding. Journal of Range Management 40, 46-48. doi: $10.2307 / 3899360$

Stepniewski W, Glinski J, Ball BC, Soane BD, van Ouwerkerk C (1994) Effects of compaction on soil aeration properties. In 'Soil compaction in crop production'. (Eds BD Soane and C van Ouwerkerk) pp. 167-189. Developments in Agricultural Engineering 11. (Elsevier Science Publishers B.V.: Amsterdam, The Netherlands)

Stirzaker RJ, Passioura JB, Wilms Y (1996) Soil structure and plant growth: impact of bulk density and biopores. Plant and Soil 185, 151-162. doi: 10.1007/BF02257571

Sun D (1990) Effect of plant age on tolerance of two grasses to simulated trampling. Australian Journal of Ecology 16, 183-188.

Unger PW, Kaspar TC (1994) Soil compaction and root growth: a review. Agronomy Journal 86, 759-766.

Ward G, Greenwood K (2002) Research and experiences in treading and wet soil management in Victoria. In 'Dairy farm soil management'. Occasional Report No. 15. Palmerston North. (Eds LD Currie and P Loganathan) pp. 47-59. (Fertiliser and Lime Research Centre, Massey University: New Zealand)

Ward G, Jacobs J, Jenkin T (2003) Impacts of sub-surface drainage and "on-off" grazing in reducing wet soil pugging damage on southern Victorian dairy pastures - some soil effects. In 'Proceedings of the 11th Australian Agronomy Conference'. Geelong, Vic. (Australian Society of Agronomy)

Warren SD, Thurow TL, Blackburn WH, Garza NE (1986) The influence of livestock trampling under intensive rotation grazing on soil hydrologic characteristics. Journal of Range Management 39, 491-495. doi: $10.2307 / 3898755$

Zegwaard KE (2006) Effects of severe cattle treading on soil physical properties and pasture productivity. Unpublished $\mathrm{PhD}$ thesis, The University of Waikato, New Zealand.

Zegwaard KE, Balks MR, Singleton PL (1998) The effect of cattle trampling and pugging on selected soil properties. In 'Proceedings of the New Zealand Soil Society Conference'. Gisborne pp. 101-102. (New Zealand Soil Science Society)

Zegwaard KE, Balks MR, Singleton PL, Thom ER, Chapman R (2000) Effect of pugging and treading duration on selected soil physical properties and pasture production-preliminary results. In 'Soil 2000: New horizons for a new century. Australian and New Zealand Second Joint Soils Conference'. Lincoln. (Eds JA Adams, AK Metherell) pp. 229-230. (Lincoln University: New Zealand)

Zou C, Sands R, Buchan G, Hudson I (2000) Least limiting water range: a potential indicator of physical quality of forest soils. Australian Journal of Soil Research 38, 947-958. doi: 10.1071/SR99108

Manuscript received 27 August 2007, accepted 12 March 2008 